\title{
COMPARING DECISIONS UNDER COMPOUND RISK AND AMBIGUITY: \\ THE IMPORTANCE OF COGNITIVE SKILLS
}

\section{Sasha Prokosheva}

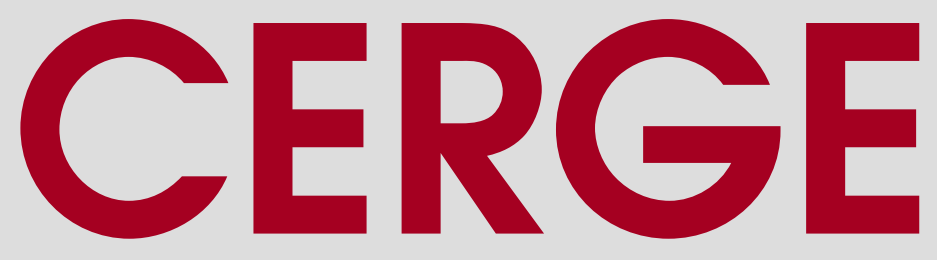




\section{Working Paper Series $\quad 525$ (ISSN 1211-3298)}

\section{Comparing Decisions under Compound Risk and Ambiguity: The Importance of Cognitive Skills}

Sasha Prokosheva

CERGE-EI

Prague, December 2014 
ISBN 978-80-7343-330-7 (Univerzita Karlova. Centrum pro ekonomický výzkum a doktorské studium)

ISBN 978-80-7344-322-1 (Akademie věd České republiky. Národohospodářský ústav) 


\title{
Comparing Decisions under Compound Risk and Ambiguity: The Importance of Cognitive Skills
}

\author{
Sasha Prokosheva* \\ $C E R G E-E I$
}

\begin{abstract}
I investigate the relationship between attitudes towards ambiguity and ability to reduce compound risks. The evidence from an experiment on adolescents shows that patterns identified in the previous literature are susceptible to experimental design and subject sample characteristics. Overall for a $20 \%$ of my subject sample, I do not observe a significant relationship between ambiguity-neutral behavior and reduction of compound lotteries. The relationship also varies with subjects' cognitive skills and the way lotteries are presented. My results caution about theoretical studies which model ambiguity preferences by relaxing the assumption of compound risk reduction, and add to the evidence against the use of compound lotteries to represent ambiguity in experiments.
\end{abstract}

\begin{abstract}
Abstrakt
V tomto článku zkoumám vztah mezi preferencemi jedinců k nejednoznačnosti a jejich schopností redukovat kombinovaná rizika. Experiment provedený se žáky druhého stupně poukazuje, že výsledky popisované v předešlých studiích jsou náchylné na změny v experimentálním designu a charakteristikách jedinců. Celkově pro asi 20 procent účastníků experimentu neexistuje vztah mezi jejich preferencemi k (ne)jednoznačnosti a schopností zredukovat složené loterie. Tento vztah dále záleží na kognitivních schopnostech účastníků a formě prezentace loterií. Výsledky nabádají k obezřetnosti při interpretaci teoretických studií modelujících preference $\mathrm{k}$ nejednoznačnosti pomocí uvolnění podmínky redukce složených loterií, a dále svědčí v neprospěch používání složených loterií k reprezentaci nejednoznačnosti v experimentech.
\end{abstract}

JEL Classification: C91 D81

Keywords: Ambiguity, cognitive ability, reduction of compound lotteries

*I am grateful to Andreas Ortmann and Ondřej Rydval for many insightful conversations and criticisms. I also thank Michal Bauer, Deborah Nováková, and the participants of the SKILLS conference at CERGE-EI for helpful discussions. I acknowledge the hospitality of the University of Passau during my visit in July 2014. The research was supported by the GACR grant P402/12-G130 awarded by the Grant Agency of the Czech Republic. All errors are my own. E-mail address: aprokosheva@gmail.com 


\section{Introduction}

Daniel Ellsberg's (Ellsberg, 1961) provoking thought experiments described situations under uncertainty when the unknown probabilities of outcomes induced some individuals to violate Subjective Expected Utility theory (SEU; Savage, 1954). Since then many studies, both theoretical and empirical, have tried to explain and accommodate this inconsistent behavior, generally termed attitude towards ambiguity (see reviews by Camerer and Weber, 1992; Etner, Jeleva and Tallon, 2012; Trautmann and Van De Kuilen, 2014). Several prominent theories (Segal, 1987, 1990; Halevy and Feltkamp, 2005; Seo, 2009) model attitudes towards ambiguity by introducing second-order probabilities and relaxing the usual reduction of compound lotteries assumption. Following Segal's (1987) example, consider a decision maker who bets on an ambiguous lottery $\left(x, A ; 0, A^{C}\right)$. She gets $x$ if the state is $A$ and 0 if the state is not $A$, but she is not aware of the distribution over the state space. In this situation, Segal (1987) and those who have since applied the same approach assume that the decision maker imagines betting on a two-staged lottery. During the first stage, the probability distribution over states is chosen out of all possible distributions, for example $\hat{p}$, where $p$ has some distribution $F$; and during the second stage the decision maker participates in the lottery $(x, \hat{p} ; 0,1-\hat{p})$. The decision maker does not know the exact value of $\hat{p}$ but knows (forms subjective beliefs about) its distribution $F$. If we assume reduction of compound lotteries, then when betting in the imaginary two-staged (ambiguous) lottery, the decision maker would be indifferent between it and the corresponding simple risky lottery. Thus, non-reduction between first- and second-stage probabilities becomes the main source of ambiguity non-neutral behavior in Segal (1987) and in the strand of literature following him.

Is relating ambiguity to compound risk a valid behavioral assumption? So far, the results from the experimental literature answering this first question are inconclusive. Whereas Halevy (2007) and Dean and Ortoleva (2014) find a close relationship between RoCL and attitudes to ambiguity, Bernasconi and Loomes (1992) and Abdellaoui, Klibanoff and Placido (2013) provide results showing a much weaker relationship between these two behavioral patterns. Interestingly, when Abdellaoui et al. (2013) juxtaposed two groups of subjects, engineering and non-engineering students, the quantitatively more advanced engineers exhibited even less association between ambiguity neutrality and RoCL. This leads to the second question: to what extent the differences in results can be explained by abilities of the participants and experimental implementation. 
In the current study I have experimentally tested how behavior under ambiguity was related to behavior under compound risk and how cognitive skills contributed to this relationship. Previous literature employed students with relatively homogenous characteristics and who likely had similar experiences with uncertain events. Moreover, some of students might have studied probability notion during their coursework, which could have led them to evaluate lotteries in ways that fit their existing knowledge. To avoid this possible bias, I used a subject sample of students with no formal education on probability. Middle-school adolescents participated in my experiment as a part of a longitudinal study on education in the Czech Republic. In a withinsubject design adolescents valued three lotteries (a risky, a compound, and an ambiguous). To reach maximum transparency and to avoid any suspicions about lottery tasks ${ }^{1}$, all lotteries were implemented in a novel physical format and subjects were incentivized with real money (Holt and Laury, 2002; Rydval et al., 2009). To address my first question, whether relating ambiguity to compound risk is a valid behavioral assumption, I investigated the robustness of the relationship between these two notions by varying lottery presentation and lottery prize. Because each subject evaluated all three lotteries, the tasks order and presentation simultaneity might have influenced the valuation outcomes (see, for example, Fox and Tversky, 1995; Chow and Sarin, 2001). Therefore, my first treatment followed Halevy (2007), when, during the evaluation stage, all the lotteries were presented at once; the second treatment followed Abdellaoui et al. (2013) and Dean and Ortoleva (2014) where subjects were shown lotteries in different order and evaluated them one by one. To answer the second question about the impact of cognitive abilities, I ran several cognitive and non-cognitive tests to track background and skills characteristics.

My findings reveal a significant number of subjects who do not comply with patterns reported in Halevy (2007) or Abdellaoui et al. (2013). I observe variation in behavior under ambiguity and compound risk, partially explained by the experimental design and background characteristics of the subject sample.

I contribute to the broader discussion on whether and how economists should model ambiguity preferences. A recent collection of articles in the journal Economics and Philosophy (2009, vol. 25) reflects this controversy. Critics like Al-Najjar and Weinstein (2009) strongly advocate for considering ambiguity non-neutral preferences as a deviation from normative behavior which

\footnotetext{
${ }^{1}$ Al-Najjar and Weinstein (2009) propose that subjects may behave ambiguity-sensitive because they expect to be manipulated when offered a bet on an ambiguous prospect. This explanation does not explain, though, why then some subjects in certain situations behave ambiguity-seeking.
} 
is not worth modeling, even for a descriptive purpose. At the same time, numerous empirical studies, both lab and field, provide evidence of the existence of ambiguity non-neutral behavior (for an overview, see Camerer and Weber, 1992; Trautmann and Van De Kuilen, 2014). The results of many of these studies cannot be explained only by aversion to possible manipulation of probabilities against the subject. However, it is not clear whether non-neutral attitudes to ambiguity are related to manifestation of some personality characteristic (thus, a quality of 'nature') or to a lack of sophistication in the source of ambiguity (thus, a quality of 'nurture'). In my experimental data I observe correlation between ambiguity-neutral behavior and cognitive skills under certain experimental conditions, therefore adding to the explanation that sophistication might play some role. I discuss related papers in the literature review section.

In terms of experimental methodology, it is important to understand the relationship between RoCL and ambiguity neutrality and whether it works through some background characteristics, because a lottery with second-order probabilities is a convenient way to design ambiguity in the lab (Maafi, 2011; Di Mauro and Maffioletti, 2004). If the background characteristics are related and if there is only weak correlation between RoCL and ambiguity neutrality, then perhaps researchers should try to find other ways to represent ambiguity (see, for example, Abdellaoui, Baillon, Placido and Wakker, 2011) and control for abilities. My results support this argument.

\section{Related experimental literature}

To my knowledge, Bernasconi and Loomes (1992) is the first paper to test the equivalence between ambiguous lotteries and two-staged (compound) lotteries. The authors ran a compound risk version of Ellsberg's three urn experiment and observed a lower number of subjects behaving as expected in experiments with ambiguous urns. Bernasconi and Loomes (1992) did not compare, however, the decisions on individual level. It is unclear how the same subject sample might behave under the same conditions but with the ambiguous urns. Therefore it is hard to evaluate the significance of their results. Moreover, the experiment considers only hypothetical answers, which may induce additional biases in valuation tasks (Camerer and Hogarth, 1999; Ortmann and Hertwig, 2006).

More recent studies by Halevy (2007), Abdellaoui et al. (2013), and Dean and Ortoleva (2014) investigated both behavior under ambiguity and compound risk on individual level, and therefore are the most relevant to my study. All three papers employed similar within-subject 
design (see Table 1 for more details).

\section{Insert Table 1 here}

Note that all three studies used student subject samples and all, except Halevy's (2007) Robustness Round, were done with computers, which arguably might create suspicion (aversion) towards ambiguous lotteries. Halevy (2007) showed that subjects who reduced compound lotteries were predominantly ambiguity-neutral, and conditional on ambiguity neutrality, most of the subjects were able to reduce compound lotteries. Dean and Ortoleva (2014) report similar results to Halevy (2007) but they ran approximately 50 different tasks, estimating various behaviors under uncertainty, of which only two were played for real. The authors themselves mentioned the possible impact of insufficient incentives. Abdellaoui et al. (2013) replicated Halevy's (2007) experiment and distinguished between two kinds of subjects: engineering and non-engineering students. Their results revealed a weaker relationship between RoCL and ambiguity neutrality than those of Halevy (2007); this was especially apparent for engineers. None of these three papers, however, explicitly tried to measure the impact of cognitive skills. Abdellaoui et al. (2013) conjectured that the differences between their results and Halevy's could be susceptible to the differences in subjects' background characteristics and their quantitative skills. Since their subject sample consisted only of students, there was a low variation in cognitive skills. Likewise, Dean and Ortoleva (2014), ran additional personality tests but point out the limitations of their student subject sample as a possible explanation for their insignificant results.

The idea to connect individual characteristics to preferences stems from psychology and recently has been studied by behavioral economists. Table 2 compares the most recent relevant papers, highlights the important experimental design features and lists the results, specifically whether cognitive or non-cognitive skills are related to risk $^{2}$ or ambiguity preferences.

\section{Insert Table 2 here}

The evidence for correlations between skills and attitudes to risk and ambiguity is mixed. A group of papers has shown that risk preferences are related to cognitive skills. People with better results on cognitive tests tend to be less risk averse (Burks et al., 2009; Dohmen et al.,

\footnotetext{
${ }^{2}$ I review papers on risk attitudes because compound risk in general represents risky situations but with a more complex decision tree. Thus, similar background characteristics may impact the decision making process when dealing with compound lotteries.
} 
2010; Benjamin et al., 2013). On contrary, some papers do not support this observation and report a non-significant relationship (Borghans et al., 2009; Booth and Nolen, 2012; Eckel et al., 2012; Sutter et al., 2013; Taylor, 2013). Whereas several studies did not find any significant correlation between ambiguity aversion and cognitive skills (Borghans et al., 2009; Dohmen et al., 2010), Rustichini et al. (2012), Sutter et al. (2013) and Dean and Ortoleva (2014) found correlation between some non-cognitive skills and attitudes to ambiguity.

There is no clear understanding of the relationship between the magnitude of ambiguity aversion and background characteristics. Yet, there is growing evidence that either individual confidence in dealing with probabilities or observing (confident) others might be related to ambiguity-neutral behavior. Psychological literature shows how individuals with different cognitive abilities can have different ways of dealing with situations involving probabilistic choice tasks. While a majority may choose a non-normative heuristics that do not require high cognitive capacity, the more intelligent minority may go for normative decisions which might be more complex but more efficient in the end (Hogarth, 1975; West and Stanovich, 2003). Chew, Ratchford and Sagi (2013) in their recent study divided subjects who correctly comprehended ambiguity tasks by probabilistically-minded (those who were able to attach probabilities for the ambiguous event) and ambiguity-minded (those who were not able to specify unknown probabilities). The latter group represented a vast majority and exhibited significantly higher ambiguity-averse attitudes than the former group. Thus, people who can more easily quantify ambiguity are perhaps more ambiguity-neutral. It is possible that those who are unsure in ambiguous situations might gain additional confidence through observing others and, thus, shift to more ambiguity-neutral behavior. Charness, Karni and Levin (2013) and Keck, Diecidue and Budescu (2014) report experiments on group decisions where subjects, after discussing decisions on choice between ambiguous and risky lotteries, were more inclined to exhibit ambiguity-neutral behavior, compared to individuals making decisions without group consultations. Similarly, Lahno and Serra-Garcia (2014) find positive correlation between cognitive abilities and shifts towards ambiguity-neutral behavior after subjects in their experiments observed other peers.

\section{Experiment}

In this study I examine the relationship between attitudes towards ambiguity and the ability to reduce compound lotteries, and test the impact of background characteristics and experimental 
implementation on this relationship.

\subsection{Participants}

The investigation was a part of a larger project on education in the Czech Republic. Schools were chosen across the entire country and the experiment was presented to every school as a part of a study process. To unify conditions for all subjects, the experiment was performed during normal school time and in CERGE-EI ${ }^{3}$ classrooms. In total eleven classes of 6 th graders ${ }^{4}$ agreed to participate. On average, a class consisted of 21 subjects.

\subsection{Design and treatments}

To test for the differences in the presentation of lotteries and lottery prize effect, I randomly assigned all classes to two treatments, each with two different lottery prizes (see Table 3).

\section{Insert Table 3 here}

Treatment At Once follows Halevy's (2007) setup, in which all lotteries were presented at once, and subjects were then asked to evaluate them. This differs from the implementation in Dean and Ortoleva (2014) and Abdellaoui et al. (2013), in which subjects evaluated lotteries one by one, so they did not know in advance either the types or the order of the compound lotteries. On the one hand, Halevy's (2007) setup might lead to anchoring and interval evaluation, when subjects choose the most preferable and the least preferable lottery and distribute their valuation of other lotteries in-between (see the comparative ignorance hypothesis by Fox and Tversky, 1995). On the other hand, whereas this representation concentrates on the difference among the lotteries, it allows one to notice the identical structures such as lottery prize and expected probability levels. This may cause some subjects to evaluate lotteries identically, which could be true especially for those acquainted with the notion of probability or with some natural understanding of it. Sequential evaluation of lotteries, however, is more vulnerable to mistakes by inattentive subjects. For example, when evaluating the final lottery in a sequence, a subject may erroneously think it has a different maximum prize than the first lottery and assign it a different value based on this belief. Therefore, to investigate the possible impact of experimental design on differences in results for the previous literature, in treatment In Order

\footnotetext{
${ }^{3}$ Center for Economic Research and Graduate Education - Economics Institute, Prague, Czech Republic.

${ }^{4}$ The first year of secondary school. On average, the subjects were 12 years old.
} 
the lotteries were presented sequentially. Importantly, to make the sequential order even more salient, I alternated every lottery evaluation with a task from an unrelated experiment ${ }^{5}$.

\subsection{Measures of preferences}

To measure risk, ambiguity and compound risk preferences I use elicitation of certainty equivalents for corresponding lotteries. A common feature for many papers employing non-student subject samples is to use Multiple Pricing List elicitation procedure (MPL, for examples and discussion see Andersen et al., 2006, 2007; Holt and Laury, 2002) rather than Becker-DeGrootMarschak method (BDM, Becker et al., 1964). For subjects from the general public, MPL procedure appears more transparent and easier to explain than BDM. Importantly, several studies have shown that BDM method for lotteries is incentive compatible only under certain assumptions and may lead to preference reversals (Karni and Safra, 1987; Keller et al., 1993; Berry et al., 2011). The negative feature of MPL is that if performed on paper, it allows elicitation of only interval values and is subject to framing effects (Andersen et al., 2006). Since the experimental subject sample consisted of adolescents, the clarity was a much higher concern, therefore I decided to implement the MPL procedure.

To evaluate the lotteries, each participant was given a simplified version of MPL with ten rows, where one column offered a bet on a lottery and the other column offered some sure amount of money, sorted ascending (see an example MPL in Appendix 1). Whenever a subject switched from one column to another, I calculated a midpoint between switching values as a certainty equivalent for the corresponding lottery. In the explanation prior to actual filling in the MPL, the subjects were shown a bag representing the corresponding lottery and all relevant details were explained. Afterwards, they were asked to fill in the answer form. The experimental assistants did not explicitly ask subjects to make only one switch, because that could have interfered with the evaluation process. Since switching between columns was not restricted, I found $22.7 \%$ of subjects (57 of 233) with inconsistent MPL choices. Their answer

\footnotetext{
${ }^{5}$ In addition to evaluation tasks, the experiments with adolescents included other unrelated tasks. A possibility exists that alternation in tasks might have created additional noise, though I tried to eliminate it. Before distributing every answer form, the experimenters explicitly re-iterated the directions for each task and confirmed that subjects understood. Additionally, I control whether the difference of order between my experiment and unrelated experiment has any significant effect on a) evaluations of all lotteries and b) differences between lottery evaluations. I do not find any significant differences. The results are reported in Appendix 2.B.
} 
forms contained at least two jumps between columns in at least one MPL task. Importantly, for the whole subject sample I observe a negative relationship between inconsistent choices in MPL tasks and cognitive abilities (reminiscent of the findings in Moon and Martin, 1996). Thus, I can partially attribute inconsistent choices to possible misunderstanding of the task or lower levels of attention. For four subjects who had exactly two jumps I applied a correction procedure to keep them in the main subject sample (see Appendix 2.A for more discussion).

The representation of ambiguous lottery is one of the most frequently criticized design features of experiments measuring ambiguity preferences (Al-Najjar and Weinstein, 2009; Hey et al., 2010). To minimize any fears of manipulation, all tasks were demonstrated using identical containers with screw caps and colors hidden under the caps (see Figure 1). Accordingly, instead of the usual colored balls or chips in opaque bags, I used transparent bags with identical containers which were different only when opened ${ }^{6}$.

In this way, the risky lottery was a bag with two red and two blue containers. The compound lottery was presented as two bags, one with one blue and three red and the other with one red and three blue containers. To create an ambiguous lottery, the experimenter took four red and four blue containers, opened and showed them to participants. The experimenter then closed them, put them into one bag and asked different subjects to draw four containers so that only four were left. As a result, neither experimenter nor subjects could know the actual distribution of colors. Then the subjects were asked explicitly what kind of distribution they expected to see in the bag and for all sessions the clear understanding was that it was impossible to say, any combination of blue and red containers could be there. Though the way the ambiguous bag was created is similar to compound lottery, I assume the subjects started to evaluate it only from the point it was already assembled.

\subsection{Measures of cognitive and non-cognitive skills}

In the experimental literature described in Table 2, researchers mainly use IQ and school tests to measure cognitive skills and Big5 test or some version of it to measure non-cognitive skills. For my experiment I ran two tests on cognitive skills, Arithmetic Test (AT) and Working Memory Test (WMT), and several tests on personality characteristics (see Rydval, 2007, for an overview of literature on cognitive and non-cognitive measurements). During the AT subjects were asked to solve simple problems grouped by four (one per each arithmetic sign) in a limited

\footnotetext{
${ }^{6}$ Later in the text I will use "red containers" and "blue containers", meaning containers with red and blue hidden colors.
} 
time. The points were assigned only for correctly solved groups, in order to induce subjects to work through every problem and thereby to ensure compatibility of results. Whereas AT tests for abilities to make calculations with accuracy and speed, WMT tests for the ability to keep information accessible in the memory. Since every subject had to evaluate three different lotteries, the working memory capacity could be an important determinant. The WMT used in the experiment was a computerized version of a working memory test (operation span) widely used in psychological literature (Turner and Engle, 1989; Engle et al., 1999). Subjects were shown different letters on a screen, one by one, and in-between they had to solve simple arithmetic problems. Afterwards, subjects had to report the letters in order they were shown. For my final analysis I exclude 18 subjects who made too many mistakes in the arithmetic calculations in WMT (above a certain threshold usually used in the literature), for robustness checks and discussion see Appendix 2.E.

\subsection{Incentives}

All tasks were incentivized with real money. Although a recent paper by Taylor (2013) claims hypothetical choices do not lead to any significant distortions, a number of studies have shown that there is a difference between valuations based on real and hypothetical tasks (Holt and Laury, 2002; Harrison et al., 2005). The same is true for evaluating risk and ambiguity preferences using self-assessment questions. Many people have different understanding and perception of their own risk-taking. Being exposed to a wider social experience may lead to a better relative understanding of risk preferences, however we cannot expect this from every subject to the same extent. Therefore, in my lottery experiment everyone was paid for one random task (out of three total lotteries). First, assistants randomly defined the lottery to be paid out (one for all participants within group). Then every subject drew a line in her MPL to be played for real - a container from a bag with ten containers numbered one to ten. Finally, the experimenter checked the choice (lottery or money) in the answer form and in the case "prefer lottery", the subject first bet the color and then drew a container from the corresponding bag, in the case "prefer money", she was given money. The actual money was distributed by class teachers after the experimental session. 


\subsection{Procedure}

Every session consisted of only one class, thus in total we ran 11 separate sessions during November 2013 - June 2014. In the morning, participants with their class teachers arrived at CERGE-EI and remained for the duration of the experiment session. All sessions were conducted in Czech by native speakers. On arrival every subject received a unique number and was asked to use only this number for identification during the whole session. The experimenters explicitly explained that all the data was anonymous and would not be used to track any individual answers. Further, experimenters randomly divided all participants into two roughly equal groups. While one group worked on experimental tasks (Tasks), the other group was doing skills tests (Tests) in a different room; when finished, the groups changed to the other task set. The Tasks were designed as pen-and-paper experiment, and took place in a usual classroom, while the Tests were conducted as both pen-and-paper and computer tests in the CERGE-EI computer lab. In Tasks, each subject evaluated three lotteries, in the Tests every subject took three tests (two cognitive skills tests and one test on personality traits). Thus, each individual observation consists of data from three tasks on lotteries and three tests.

On average each session lasted 2.5 hours with one break; all participants received a small snack between the Tasks and Tests.

\section{Results}

In total 233 subjects participated in the experiment. As described in the sections Measures of preferences and Measures of cognitive and non-cognitive skills, I dropped several subjects with inconsistent answers, therefore the remaining analysis is based on the data from 162 subjects.

\subsection{Lotteries and tests statistics}

Following related literature (Halevy, 2007; Borghans et al., 2009) I define measures of compound risk (ambiguity) aversion as differences between risky and compound (ambiguous) lottery valuations weighted by maximum lottery prize (see Table 4 for the exact description of all variables). Table 5 shows descriptive statistics for lottery valuations and cognitive tests by lottery prize.

\section{Insert Table 4 and Table 5 here}

The larger the difference the more averse is the subject; whenever the difference is zero, $L_{R}=L_{C}\left(L_{R}=L_{A}\right)$, the subject is indifferent to compound risk (ambiguity-neutral). I per- 
form several robustness checks in Appendix 2, to determine whether order of tasks, lottery prize, or mid-list problem ${ }^{7}$ have any impact on lottery reservation prices. Though there is evidence of subjects being more risk averse (mean $R A_{200}>$ mean $R A_{100}$ ) in the tasks with a higher lottery prize (as in Holt and Laury, 2002), there is no significant difference for attitudes towards ambiguity $\left(A A_{r e l}\right)$ or RoCL $\left(C A_{r e l}\right)$ depending on prize amount. For both measures, the Wilcoxon-Mann-Whitney (WMW) test cannot reject the null hypothesis of no difference between two sub-samples with lottery prizes in the amounts of 100 CZK and 200 CZK. Analogously, neither order of tasks, nor the mid-list problem have any significant impact on $C A_{\text {rel }}$ and $A A_{\text {rel }}$.

Similar to Halevy (2007), measures of risk, compound risk and ambiguity are positively correlated (see Table 6). The reason could be that subjects found it difficult to evaluate lotteries separately, and they likely approached this by making comparison with other lotteries; however, there is no significant difference in ambiguity aversion $\left(A A_{r e l}\right)$ and compound risk aversion measures $\left(C A_{r e l}\right)$ between treatments (WMW tests are not rejected) when lotteries were shown At Once (as in Halevy, 2007) and In Order (as in Abdellaoui et al., 2013; Dean and Ortoleva, 2014).

\section{Insert Table 6 here}

The correlations between the main test measures are presented in Table 7 . The correlation is positive between cognitive skills measurements, though we can see that the AT and the WMT capture different attributes of cognitive skills (see Figure 2 for distributions on cognitive tests results).

\section{Insert Table 7 here}

Math anxiety, as expected, is positively correlated with AT score - the less subjects are anxious about mathematical tasks, the higher results they achieve on the AT. Other psychological characteristics and background variables are not significantly correlated with cognitive tests results.

\footnotetext{
${ }^{7}$ Tendency to provide focal values; for MPLs, two middle rows can be a focal point for switching.
} 


\subsection{Ambiguity preferences and RoCL}

Table 8 compares data from existing literature and from the current study. For my subject sample we can see a significant relationship between ambiguity-neutral behavior and RoCL (2-sided Fisher test rejects the hypothesis of no relationship).

\section{Insert Table 8 here}

Though this pattern supports the findings from the previous literature, the results of my experiment differ in two important ways. First, my subject sample has a higher proportion of subjects both reducing compound lotteries and being ambiguity-neutral, $43 \%$ of subjects provided the same values to compound lottery and risky lottery and $42 \%$ of subjects were ambiguity-neutral (versus 16\%/20\% in Halevy (2007), 15\%/26\% in Abdellaoui et al. (2013), and 20\%/19\% in Dean and Ortoleva (2014)). Similarly, Chew et al. (2013) observed a relatively low level of ambiguity aversion when considering their whole subject sample. However, for the group that passed a comprehension task above certain measure, the level of ambiguity aversion was higher. Chew et al. conjecture that complexity might drive people to make inattentive choices, thus they exhibit lower levels of ambiguity aversion. Is is possible that in my experiment, some adolescents were less attentive and therefore set identical values for all three urns. If so, we should expect children with lower cognitive skills to be in this group; however, the results from the next subsection reveal that this is not the case.

Second, 17 of 22 subjects in Halevy (2007) who set the same values for all lotteries chose the focal (mid-list) values. For example, for the binary lottery with probabilities $1 / 2$ and outcomes 0 and 2, subjects chose 1 for all lotteries. We can only guess about the reasoning applied, but if indeed the choice was driven by mid-list value, the data pattern reported by Halevy becomes less evident. In my paper I observe neither mid-list problem for any lottery valuations, nor any focal point in data for this group (see Appendix 2.D for more discussion).

Importantly, Halevy (2007) and Abdellaoui et al. (2013) use several compound lotteries, thus their condition for reduction of compound lotteries was stricter. Dean and Ortoleva (2014) and my study use only one compound lottery. Table 9 shows results from Halevy (2007) when the condition of compound lottery reduction is based only on one lottery ${ }^{8}$. Given ambiguityneutral behavior, approximately the same proportion of subjects are able to reduce a compound lottery, regardless of what type of compound lottery and how many are at stake. However,

\footnotetext{
${ }^{8}$ Data was taken from Halevy (2007), calculations are my own.
} 
for those who follow RoCL, the proportion of ambiguity-neutral and ambiguity non-neutral subjects seems to depend on the number and type of compound lotteries under consideration. For example, when a compound lottery is easier to comprehend (like degenerate lottery V4 in Halevy, 2007), then we can observe more subjects reducing compound risk but remaining ambiguity non-neutral.

\section{Insert Table 9 here}

For my data, this could imply that if subjects were given several compound lotteries, the relationship could be driven in the direction of Abdellaoui et al.'s (2013) results. At the same time the difference between distributions in cells $\mathrm{V} 1=\mathrm{V} 3=\mathrm{V} 4$ and $\mathrm{V} 1=\mathrm{V} 3$ in Table 9 is minor. But in general it is not clear what impact the evaluation of additional compound lotteries would have on the distribution of results in the experiments à la Halevy (2007). Thus, the experimental design might have significant impact on the interpretation.

\subsection{Variation with background}

First, to compare data to the previous studies, I have divided the entire subject sample into two groups by WMT and AT results (WMT score and AT score), see Table 10. Additionally, I used data from Halevy (2007) and created a similar division for his subject sample. In the group Major 0 I have included all subjects with major in humanities or social sciences that usually involve less mathematical sophistication. Group Major 1 includes subjects with majors requiring more exposure to mathematics. 27 subjects did not report their major, 22 of them were in the group with $A m b N=0$ and $R o C L=0$. We can observe for my data, similar to Halevy, that being on a diagonal in the table (stronger relationship between RoCL and ambiguity neutrality) becomes more salient for subjects with better mathematical skills (majors requiring mathematics courses for Halevy). There is no such pattern for WMT score or for the data from Abdellaoui et al. (2013).

\section{Insert Table 10 here}

Table 11 reports the results for effect of cognitive skills on ambiguity-neutral behavior and ability to reduce compound lotteries for the entire subject sample. Columns (1) and (3) show the effect of cognitive skills without controls, and columns (2) and (4) include controls for gender and whether subjects come from the capital (Prague), a crude proxy for socioeconomic 
status $^{9}$.

\section{Insert Table 11 here}

We can see significant relationship between RoCL and AT scores, but not with WMT scores. Additionally, the variable female is positively related to RoCL. However, I do not find any significant relationship between ambiguity-neutral behavior and cognitive skills. These results correspond to studies by Borghans et al. (2009) and Rustichini et al. (2012). For both RoCL and ambiguity-neutral behavior I observe negative significant relationship with gender: being female, leads to a lower probability to reduce compound lotteries or be ambiguity-neutral. Contrary to many studies relating ambiguity to personality traits, I do not observe any significant relationship between measures of non-cognitive skills and ambiguity neutrality or ability to reduce compound lotteries.

\subsection{Variation with background by treatments}

Table 12 presents the experimental data, divided by two sub-samples depending on how the lotteries were presented to the subjects. If we compare count data, we can observe approximately the same distribution of subjects among groups. The only difference is a slight increase in the number of individuals who reduce compound lotteries in the treatment At once.

\section{Insert Table 12 here}

We can see, however, a difference between the two treatments, At once and In order, when we analyze how cognitive skills impact attitudes to ambiguity and to compound risk. While I do not find any significant relationship for the treatment when lotteries were shown sequentially, I observe significant relationship for the treatment when all lotteries were shown at once (see Table 13).

\section{Insert Table 13 here}

Those who had higher results in AT and WMT were more likely to reduce compound lotteries and to be ambiguity-neutral. Halevy (2007) reports that in his experiment those who had more training in mathematics set equal (focal) values for all lotteries. Obviously, my subject sample has no training in advanced mathematics and I was not running additional tests asking

\footnotetext{
${ }^{9}$ The average wage in Prague is approximately $30 \%$ higher than in other regions of the Czech Republic.
} 
them to explain their choices, therefore I can only conjecture about the underlying reasoning. Still, it seems that differences in Halevy's (2007) design and that of Abdellaoui et al. (2013) could lead to differences in results: presenting all lotteries at once might make it more likely for subjects more inclined to mathematics to value them identically.

\section{Conclusion}

The main finding from my experiment is that although the relationship between attitudes to ambiguity and compound risk may be significant in some implementations, it is highly susceptible to experimental design and background characteristics. Approximately $20 \%$ of my subject sample do not exhibit association between ambiguity neutrality and reduction of compound lotteries.

First, when considering the entire subject sample, the estimation results demonstrate that those performing better on the AT are more likely to reduce compound lotteries; however, this does not hold for WMT measurement. Importantly, cognitive tests results are not significant when evaluating behavior under ambiguity. These findings do not support the observation of Abdellaoui et al. (2013) that more quantitatively sophisticated subjects perform less inline with Halevy's (2007) results.

Second, when considering sub-samples divided by the way lotteries were presented to the subjects (all at once or one at a time), I find evidence that, for RoCL, the effect is generated by those subjects who were presented with all lotteries at once. Therefore, differences in design of experiments by Halevy (2007) and Abdellaoui et al. (2013) could add to differences in the results.

The presented experiment suggests that behavior under compound risk and ambiguity might be driven by different background characteristics, therefore models or experimental designs that equalize these two notions, may provide questionable results. 
Appendix 1: Instructions (MPL form for a lottery with 100 CZK prize) $)^{10}$

STUDENT ID:

\section{INSTRUCTIONS}

In every row, please, make a cross in either the left or right square.

- If you cross the left square, then it means you would like to draw a ball from the bag. In case you guess the color correctly, you will win $100 \mathrm{CZK}$.

- If you cross the right square, then it means for this row you would like to receive a sure amount of money stated there.

Remember that you do not know yet what row will be played in the end of the experiment. Your final reward will depend on which row you draw and what choice you make there.

$\begin{array}{llll}\text { Row [1] } & \text { Draw a ball } \square & \mid & \text { Receive money, 10 CZK } \\ \text { Row [2] } & \text { Draw a ball } \square & \mid & \text { Receive money, 20 CZK } \\ \text { Row [3] } & \text { Draw a ball } \square & \mid & \text { Receive money, 30 CZK } \\ \text { Row [4] } & \text { Draw a ball } \square & \mid & \text { Receive money, 40 CZK } \\ \text { Row [5] } & \text { Draw a ball } \square & \mid & \text { Receive money, 50 CZK } \\ \text { Row [6] } & \text { Draw a ball } \square & \mid & \text { Receive money, 60 CZK } \\ \text { Row [7] } & \text { Draw a ball } \square & \mid & \text { Receive money, 70 CZK } \\ \text { Row [8] } & \text { Draw a ball } \square & \text { Receive money, 80 CZK } \\ \text { Row [9] } & \text { Draw a ball } \square & \text { Receive money, 90 CZK } \\ \text { Row [10] } & \text { Draw a ball } \square & \text { Receive money, 100 CZK }\end{array}$

${ }^{10}$ Translation from Czech 


\section{Appendix 2: Sensitivity analysis}

\section{A: Inconsistent MPLs}

4 subjects of 57 with inconsistent MPL choices had only one jump between columns, which looked like an outlier in the evaluation pattern (see an example in Table 14). To define the certainty equivalent in this case, I added all rows with lottery choice on the left side and added all rows with money choice on the right side, and then the certainty equivalent was defined as the value in-between (55 in the provided example).

\section{Insert Table 14 here}

Table 15 reports the results from estimating the effect of cognitive skills on whether the subject made inconsistent choices in MPL. The coefficient for AT score is positive and significant at the 5 percent level. The probability to make inconsistent choices is 10.2 percentage points less for a one point higher score in AT (number of correctly solved groups).

\section{Insert Table 15 here}

\section{B: Order effect}

To control for order effects, the lotteries were presented in different order (differed by classes). Harrison et al. (2005) show that a lottery which comes later in a series of lottery valuations may be valued less than the lotteries that preceded it. Thus, subjects exhibit more risk aversion in later tasks. Halevy (2007), in contrast, finds an opposite effect in his data. It is possible that some subjects might be more cautious when seeing the lottery task for the first time, and thus assign lower values. Further valuation tasks may already seem familiar, therefore the valuations would be shifted upwards. Table 16 shows mean valuations for each lottery in my experiment depending on the order it was presented. There is a slight decrease on average for valuations of 100 CZK lotteries (contrary to Halevy, 2007); however, there is no clear trend for the $200 \mathrm{CZK}$ lotteries. To test for order effects on valuation, I investigate both the impact of being presented first (versus after) some other lottery and the impact of order relative to other lotteries.

\section{Insert Table 16 here}

1) Does lottery valuation depend on the absolute order of presentation (whether the lottery 
was presented first versus second or third)?

To test for this possible bias, I compare $\mathrm{MPL}_{R}\left(\mathrm{MPL}_{C}\right.$ or $\left.\mathrm{MPL}_{A}\right)$ value when a lottery was valued first out of all three lotteries to $\mathrm{MPL}_{R}\left(\mathrm{MPL}_{C}\right.$ or $\left.\mathrm{MPL}_{A}\right)$ when a lottery was valued second or third. From Table 17, the order of presentation did not impact the results: For all lotteries I cannot reject the test of difference in means at $5 \%$ level. There is some evidence of difference in valuations for the ambiguous lottery in 100 CZK treatment (the ambiguous lottery was valued slightly higher when it was presented first). However, this difference is not significant at 5\% level, and could attributed at least partially to MPL procedure which allows estimation only of interval values.

\section{Insert Table 17 here}

2) Does lottery valuation depend on the relative order of presentation?

Table 18 presents the results of tests performed separately by prize. For example, in the first line of the table I test whether mean value of risky lottery differs for groups that were presented this lottery before (as opposed to after) the compound lottery. Similar to the first question, all differences in means are insignificant with marginal significance for ambiguous lottery in the 100 CZK task.

\section{Insert Table 18 here}

3) Does lottery valuation depend on the order relative to unrelated experimental tasks?

Table 19 shows all tests are insignificant, therefore we cannot reject the hypothesis of differences between valuations depending on order with unrelated experimental tasks.

\section{Insert Table 19 here}

\section{C: Size of the lottery prize}

Does lottery prize amount have any effect on $\mathrm{CA}_{\text {rel }}$ and $\mathrm{AA}_{\text {rel }}$ (attitudes towards compound risk and ambiguity relative to risk)? For all the lottery valuations, Wilcoxon-Mann-Whitney test cannot be rejected (see Table 20).

\section{Insert Table 20 here}




\section{D: Mid-list problem}

A potential problem for MPL procedure is that some subjects might switch from the lottery column to the sure amount column exactly in the middle of pricing list because they might subconsciously wish to make their answer look symmetric and not because this is their true value (see a discussion in Andersen et al., 2006). I test whether the median differs from the mid-list value for each lottery valuation. For all variables, Wilcoxon sign-rank test rejects the null hypothesis of equality between mid-list value and median lottery valuation (see Table 21).

\section{Insert Table 21 here}

Figure 5 shows distributions of valuations versus mean values.

\section{Insert Figure 5 here}

\section{E: Low accuracy on the math operations in WMT}

Following the literature in psychology (Engle et al., 1999; De Neys et al., 2002; Unsworth et al., 2005), I excluded from analysis 18 subjects who could not accurately solve mathematical equations during WM test. Usually, studies require accuracy rate above $85 \%$. Since I am dealing with adolescents, I decreased this rate to $75 \%$, thus everyone who made more than 18 errors in mathematical equations was excluded. In Table 22 and Table 23 I provide the analysis of the data if I exclude everyone who did not comply with an $85 \%$ accuracy rate (31 subjects in total). The relationships between the main variables (AmbN and RoCL) and cognitive skills remain significant as in the main analysis.

\section{Insert Table 22 and Table 23 here}




\section{References}

Abdellaoui, M., Baillon, A., Placido, L. and Wakker, P. P. (2011) The rich domain of uncertainty: Source functions and their experimental implementation, American Economic Review, 101, 695-723.

Abdellaoui, M., Klibanoff, P. and Placido, L. (2013) Experiments on compound risk in relation to simple risk and to ambiguity, Mimeo.

Al-Najjar, N. I. and Weinstein, J. (2009) The ambiguity aversion literature: A critical assessment, Economics and Philosophy, 25, 249-284.

Andersen, S., Harrison, G. W., Lau, M. I. and Rutström, E. E. (2006) Elicitation using multiple price list formats, Experimental Economics, 9, 383-405.

Andersen, S., Harrison, G. W., Lau, M. I. and Rutström, E. E. (2007) Valuation using multiple price list formats, Applied Economics, 39, 675-682.

Becker, A., Deckers, T., Dohmen, T., Falk, A. and Kosse, F. (2012) The relationship between economic preferences and psychological personality measures, Annual Review of Economics, 4, 453-478.

Becker, G. M., Degroot, M. H. and Marschak, J. (1964) Measuring utility by a single-response sequential method, Behavioral Science, 9, 226-232.

Benjamin, D. J., Brown, S. A. and Shapiro, J. M. (2013) Who is 'behavioral'? Cognitive ability and anomalous preferences, Journal of the European Economic Association, 11, 1231-1255.

Bernasconi, M. and Loomes, G. (1992) Failures of the reduction principle in an Ellsberg-type problem, Theory and Decision, 32, 77-100.

Berry, J., Fischer, G. and Guiteras, R. (2011) Incentive compatibility in the field: A test of the Becker-De Groot-Marschak mechanism, mimeo.

Booth, A. L. and Katic, P. (2013) Cognitive skills, gender and risk preferences, Economic Record, 89, 19-30.

Booth, A. L. and Nolen, P. (2012) Gender differences in risk behaviour: Does nurture matter?, The Economic Journal, 122, F56-F78.

Borghans, L., Heckman, J. J., Golsteyn, B. H. H. and Meijers, H. (2009) Gender differences in risk aversion and ambiguity aversion, Journal of the European Economic Association, 7, 649-658.

Burks, S. V., Carpenter, J. P., Goette, L. and Rustichini, A. (2009) Cognitive skills affect economic preferences, strategic behavior, and job attachment, Proceedings of the National Academy of Sciences.

Camerer, C. and Weber, M. (1992) Recent developments in modeling preferences: uncertainty and ambiguity, Journal of Risk and Uncertainty, 5, 325-370.

Camerer, C. F. and Hogarth, R. M. (1999) The effects of financial incentives in experiments: A review and capital-labor-production framework, Journal of Risk and Uncertainty, 19, 7-42. 
Charness, G., Karni, E. and Levin, D. (2013) Ambiguity attitudes and social interactions: An experimental investigation, Journal of Risk and Uncertainty, 46, 1-25.

Chew, S. H., Ratchford, M. and Sagi, J. S. (2013) You need to recognize ambiguity to avoid it, SSRN scholarly paper, Social Science Research Network.

Chow, C. C. and Sarin, R. K. (2001) Comparative ignorance and the Ellsberg paradox, Journal of Risk and Uncertainty, 22, 129-139.

De Neys, W., D’Ydewalle, G., Schaeken, W. and Vos, G. (2002) A dutch, computerized, and group administrable adaptation of the operation span test, Psychologica Belgica, 42, 177-190.

Dean, M. and Ortoleva, P. (2014) Is it all connected? A testing ground for unified theories of behavioral economics phenomena, Mimeo.

Di Mauro, C. and Maffioletti, A. (2004) Attitudes to risk and attitudes to uncertainty: Experimental evidence, Applied Economics, 36, 357-372.

Dohmen, T., Falk, A., Huffman, D. and Sunde, U. (2010) Are risk aversion and impatience related to cognitive ability?, American Economic Review, 100, 1238-1260.

Eckel, C. C., Grossman, P. J., Johnson, C. A., Oliveira, A. C. M., Rojas, C. and Wilson, R. K. (2012) School environment and risk preferences: Experimental evidence, Journal of Risk and Uncertainty, 45, 265-292.

Ellsberg, D. (1961) Risk, ambiguity, and the Savage axioms, The Quarterly Journal of Economics, 75, 643-669.

Engle, R. W., Tuholski, S. W., Laughlin, J. E. and A, R. (1999) Working memory, short-term memory, and general fluid intelligence: A latent-variable approach, Journal of Experimental Psychology: General, 128, 309-331.

Etner, J., Jeleva, M. and Tallon, J.-M. (2012) Decision theory under ambiguity, Journal of Economic Surveys, 26, 234-270.

Fox, C. and Tversky, A. (1995) Ambiguity aversion and comparative ignorance, The Quarterly Journal of Economics, 110, 585-603.

Frederick, S. (2005) Cognitive reflection and decision making, The Journal of Economic Perspectives, 19, 25-42.

Halevy, Y. (2007) Ellsberg revisited: An experimental study, Econometrica, 75, 503-536.

Halevy, Y. and Feltkamp, V. (2005) A Bayesian approach to uncertainty aversion, The Review of Economic Studies, 72, 449-466.

Harrison, G. W., Johnson, E., Mcinnes, M. M. and Rutström, E. E. (2005) Risk aversion and incentive effects: Comment, American Economic Review, 95, 897-901.

Hey, J. D., Lotito, G. and Maffioletti, A. (2010) The descriptive and predictive adequacy of theories of decision making under uncertainty/ambiguity, Journal of Risk and Uncertainty, 41, 81-111.

Hogarth, R. M. (1975) Cognitive processes and the assessment of subjective probability distributions, Journal of the American Statistical Association, 70, 271. 
Holt, C. A. and Laury, S. K. (2002) Risk aversion and incentive effects, American Economic Review, 92, 1644-1655.

Karni, E. and Safra, Z. (1987) "Preference reversal" and the observability of preferences by experimental methods, Econometrica, 55, 675.

Keck, S., Diecidue, E. and Budescu, D. (2014) Group decisions under ambiguity: Convergence to neutrality, Journal of Economic Behavior $\&$ Organization.

Keller, L. R., Segal, U. and Wang, T. (1993) The Becker-De Groot-Marschak mechanism and generalized utility theories: Theoretical predictions and empirical observations, Theory and Decision, 34, 83-97.

Lahno, A. M. and Serra-Garcia, M. (2014) Peer effects in risk taking, SSRN Scholarly Paper ID 2204956, Social Science Research Network.

Maafi, H. (2011) Preference reversals under ambiguity, Management Science, 57, 2054-2066.

Moon, P. and Martin, A. (1996) The search for consistency in economic search, Journal of Economic Behavior \&5 Organization, 29, 311-321.

Ortmann, A. and Hertwig, R. (2006) Monetary incentives: Usually neither necessary nor sufficient?, SSRN Scholarly Paper ID 1129845, Social Science Research Network.

Rustichini, A., DeYoung, C. G., Anderson, J. E. and Burks, S. V. (2012) Toward the integration of personality theory and decision theory in the explanation of economic and health behavior, IZA Discussion Paper 6750, Institute for the Study of Labor (IZA).

Rydval, O. (2007) Financial incentives and cognitive abilities: Evidence from a forecasting task with varying cognitive load, Jena Economic Research Paper 2007-040, Friedrich-SchillerUniversity Jena, Max-Planck-Institute of Economics.

Rydval, O., Ortmann, A., Prokosheva, S. and Hertwig, R. (2009) How certain is the uncertainty effect?, Experimental Economics, 12, 473-487.

Savage, L. J. (1954) The Foundations of Statistics, Wiley Publications in Statistics.

Segal, U. (1987) The Ellsberg paradox and risk aversion: An anticipated utility approach, International Economic Review, 28, 175-202.

Segal, U. (1990) Two-stage lotteries without the reduction axiom, Econometrica, 58, 349.

Seo, K. (2009) Ambiguity and second-order belief, Econometrica, 77, 1575-1605.

Sutter, M., Kocher, M. G., Glätzle-Rützler, D. and Trautmann, S. T. (2013) Impatience and uncertainty: Experimental decisions predict adolescents' field behavior, American Economic Review, 103, 510-531.

Taylor, M. P. (2013) Bias and brains: Risk aversion and cognitive ability across real and hypothetical settings, Journal of Risk and Uncertainty, 46, 299-320.

Trautmann, S. T. and Van De Kuilen, G. (2014) Ambiguity attitudes, in Handbook of Judgment and Decision Making, Blackwell, G. Keren and G. Wu edn. 
Turner, M. L. and Engle, R. W. (1989) Is working memory capacity task dependent?, Journal of Memory and Language, 28, 127-154.

Unsworth, N., Heitz, R. P., Schrock, J. C. and Engle, R. W. (2005) An automated version of the operation span task, Behavior Research Methods, 37, 498-505.

West, R. F. and Stanovich, K. E. (2003) Is probability matching smart? Associations between probabilistic choices and cognitive ability, Memory \& Cognition, 31, 243-251. 


\section{Tables}

Table 1: Experimental designs comparison for the literature studying relationship between RoCL and attitudes towards ambiguity

\begin{tabular}{|c|c|c|c|c|c|}
\hline & $\mathrm{H} 2007, \mathrm{ME}$ & H 2007, RR & A 2013, ST2 & A 2013, ST3 & D\&O 2014 \\
\hline Sample size & 104 & 38 & 115 & 64 & 190 \\
\hline Sample structure & $\begin{array}{l}\text { All students who } \\
\text { signed-up for slots }\end{array}$ & $\begin{array}{l}\text { Proportional sam- } \\
\text { pling within co- } \\
\text { horts }\end{array}$ & $\begin{array}{l}75 \text { engineering, } 40 \\
\text { all other fields }\end{array}$ & $\begin{array}{l}51 \text { engineering, } 13 \\
\text { quantitative eco- } \\
\text { nomics }\end{array}$ & $\begin{array}{l}\text { All students who } \\
\text { signed-up for slots }\end{array}$ \\
\hline Implementation & Computerized & Physical & Computerized & $\begin{array}{l}\text { Computerized } \\
\text { (subject verbal- } \\
\text { ized, experimenter } \\
\text { entered choices) }\end{array}$ & Computerized \\
\hline Framing & Boxes and balls & Boxes and chips & Balls in urns drawn & on the screen & Bags and chips \\
\hline Elicitation & $\mathrm{BDM}$ & $\mathrm{BDM}$ & Iterative choice list & rocedure ${ }^{1}$ & MPLs \\
\hline Probability levels & $1 / 2$ for all & $1 / 2$ for all & $1 / 2$ for all & $1 / 12,1 / 2,11 / 12$ & $1 / 2$ for all \\
\hline Order of tasks ${ }^{2}$ & $\begin{array}{l}4 \text { tasks in order: } \\
\mathrm{R}, \mathrm{A}, \mathrm{C} 1, \mathrm{C} 2 . \text { Lot- } \\
\text { teries presented at } \\
\text { once }\end{array}$ & $\begin{array}{l}4 \text { tasks, different } \\
\text { orders: R, A, C1, } \\
\text { C2. Lotteries pre- } \\
\text { sented at once }\end{array}$ & $\begin{array}{l}5 \text { tasks, different } \\
\text { orders: } \mathrm{R}, \mathrm{A}, \mathrm{C} 1 \text {, } \\
\text { var of } \mathrm{C} 1, \mathrm{C} 2\end{array}$ & $\begin{array}{l}32 \text { tasks in order: } \\
\mathrm{R}(4), \mathrm{A}(7), \mathrm{C}(21)\end{array}$ & $\begin{array}{l}9 \text { tasks }(3 \text { per } \\
\text { each prize) in or- } \\
\text { der: } \mathrm{R}(3), \mathrm{A}(3) \text {, } \\
\mathrm{C} 2(3)\end{array}$ \\
\hline Lottery prize & $\$ 2$ & $\$ 20$ & $€ 50$ & $€ 50$ & $\$ 6, \$ 8, \$ 10$ \\
\hline Payments & \multicolumn{2}{|c|}{ Every lottery was played and paid } & \multicolumn{2}{|c|}{ One random task was played and paid } & $\begin{array}{l}2 \text { lotteries of } 50 \\
\text { were played for } \\
\text { real }\end{array}$ \\
\hline
\end{tabular}

Notes: H 2007, ME and RR = Halevy (2007), Main Experiment and Robustness Round with higher stakes;

D\&O $2014=$ Dean and Ortoleva (2014);

A 2013, ST2 and ST3 = Abdellaoui et al. (2013), Study 2 and Study 3;

${ }^{1}$ Iterative choice list procedure $=$ computerized version of MPL, see Abdellaoui et al. (2011);

${ }^{2} \mathrm{R}=$ Risky lottery; $\mathrm{A}=$ Ambiguous lottery, $\mathrm{C} 1$ = Compound lottery, 2 colors, uniform distribution; C $2=\mathrm{Compound}$ lottery, either all of one

color or all of the other color. 
Table 2: Literature on relationship between personality traits and attitudes towards risk/ambiguity

\begin{tabular}{|c|c|c|c|c|c|c|c|}
\hline \multirow{2}{*}{ Study } & \multirow{2}{*}{$\begin{array}{l}\text { Sample size } \\
\text { Age }\end{array}$} & \multirow{2}{*}{$\begin{array}{l}\text { Measured } \\
\text { attitudes }\end{array}$} & \multirow{2}{*}{$\begin{array}{l}\text { Framing } \\
\text { Elicitation }\end{array}$} & \multirow{2}{*}{$\begin{array}{l}\text { Tests Cogn } \\
\text { Tests NCogn }\end{array}$} & \multicolumn{3}{|c|}{ Results } \\
\hline & & & & & $\begin{array}{l}\text { majority is } \\
\mathrm{RA} / \mathrm{AA}\end{array}$ & $\begin{array}{l}\text { related to } \\
\text { Cogn }\end{array}$ & $\begin{array}{l}\text { related to } \\
\text { NCogn }\end{array}$ \\
\hline \multirow{2}{*}{$\begin{array}{l}\text { Borghans et al. } \\
2009\end{array}$} & R 347 & \multirow{2}{*}{$\begin{array}{l}\text { Risk, } \\
\text { Ambiguity }\end{array}$} & Urns & RavenIQ & \multirow{2}{*}{ yes/yes } & R: NS & $\mathrm{R}:$ mixed \\
\hline & 15-16 у.о. & & BDM & $\begin{array}{l}\text { Big5, Ambition, } \\
\text { SelfCtrl, FlexTh }\end{array}$ & & A: NS & A: NS \\
\hline \multirow[t]{2}{*}{$\begin{array}{l}\text { Burks et al. } \\
2009\end{array}$} & R 1066 & \multirow[t]{2}{*}{ Risk } & Lottery & $\begin{array}{l}\text { RavenIQ, Hit15, } \\
\text { NumETS }\end{array}$ & \multirow[t]{2}{*}{$-/-$} & \multirow[t]{2}{*}{ yes } & \multirow[t]{2}{*}{ mixed } \\
\hline & $\begin{array}{l}\text { trainee } \\
\text { truckers }\end{array}$ & & MPLs & MPQ & & & \\
\hline $\begin{array}{l}\text { Dohmen et al. } \\
2010\end{array}$ & $\begin{array}{l}\text { R } 902 \\
>17 \text { y.o. }\end{array}$ & Risk & $\begin{array}{l}\text { Lottery } \\
\text { MPLs }\end{array}$ & $\begin{array}{l}\text { similar to WAIS } \\
\text { Big5 }\end{array}$ & yes $/-$ & yes & NS \\
\hline $\begin{array}{l}\text { Becker et al. } \\
2012\end{array}$ & $\begin{array}{l}\text { ST } 489 \\
\text { students } \\
\overline{\mathrm{R}} \overline{9} \overline{\mathrm{C}}--- \\
\geq 17 \text { y.o. } \\
\overline{\mathrm{R}} \overline{1} \overline{14,2 \overline{4} 3}-- \\
\text { SOEP }\end{array}$ & $\begin{array}{l}\text { Risk } \\
------ \\
\text { Risk } \\
------ \\
\text { Risk }\end{array}$ & $\begin{array}{l}\text { Lottery } \\
\text { MPLs } \\
\overline{\text { Lottery }}---- \\
\text { MPLs } \\
\text { Self- }----- \\
\text { assessment }\end{array}$ & $\begin{array}{l}- \\
\text { versBig5, LoC } \\
----- \\
\text { versBig5 }----- \\
- \\
\text { versBig5, LoC }\end{array}$ & $\begin{array}{l}-/- \\
----- \\
-/- \\
------ \\
-/-\end{array}$ & $\begin{array}{l}- \\
----- \\
- \\
------ \\
-\end{array}$ & $\begin{array}{l}\text { mixed } \\
------- \\
\text { mixed } \\
------- \\
\text { yes }\end{array}$ \\
\hline \multirow{2}{*}{$\begin{array}{l}\text { Booth and } \\
\text { Nolen } 2012\end{array}$} & R 260 & \multirow{2}{*}{ Risk } & Lottery & Mazes & \multirow{2}{*}{ yes /- } & \multirow{2}{*}{ NS } & \multirow{2}{*}{-} \\
\hline & $\approx 15 \mathrm{y} \cdot \mathrm{o}$ & & $\begin{array}{l}\text { Choice, Self- } \\
\text { assessment }\end{array}$ & - & & & \\
\hline \multirow{2}{*}{$\begin{array}{l}\text { Eckel et al. } \\
2012\end{array}$} & R 490 & Risk & Visual, choice & NumETS & yes /- & NS & mixed \\
\hline & $\begin{array}{l}9 \text { th-11th } \\
\text { graders }\end{array}$ & & among circles & $\begin{array}{l}\text { Psychometric } \\
\text { scales }\end{array}$ & & & 1111 АСด \\
\hline Benjamin & $\mathrm{R} 92+\mathrm{R} 81$ & Risk & Lottery & $\begin{array}{l}\text { Standardized test } \\
\text { (similar to SAT) }\end{array}$ & $-/-$ & yes & - \\
\hline & $\begin{array}{l}\text { high school } \\
\text { seniors }\end{array}$ & & MPLs & - & & & \\
\hline $\begin{array}{l}\text { Booth and } \\
\text { Katic } 2013\end{array}$ & R 1586 & Risk Hyp & $\begin{array}{l}\text { Lottery, Self- } \\
\text { assessment }\end{array}$ & $\begin{array}{l}\text { Ranking for uni- } \\
\text { versity entrance }\end{array}$ & yes $/-$ & NS & - \\
\hline & 18 y.o. & & & - & & & \\
\hline Rustichini & R 1065 & Risk, & Lottery & $\begin{array}{l}\text { RavenIQ, Hit15, } \\
\text { NumETS }\end{array}$ & - & R: yes & $\mathrm{R}$ : mixed \\
\hline & $\begin{array}{l}\text { trainee } \\
\text { truckers }\end{array}$ & & MPLs & MPQ & & A: NS & A: mixed \\
\hline Sutter et al. & R 661 & Risk, & Lottery & $\begin{array}{l}\text { German/Math } \\
\text { grade }\end{array}$ & yes/yes & R: NS & - \\
\hline 2013 & 10-18 у.о. & Ambiguity & MPLs & - & & A: mixed & \\
\hline Taylor 2013 & ST 98 & Risk, Risk & Lottery & $\begin{array}{l}\text { CRT, Numeracy } \\
\text { test }\end{array}$ & yes $/-$ & Real: NS & - \\
\hline & undergrad & & MPLs & - & & Hyp: yes & \\
\hline Dean and & ST 190 & Risk, & Lottery, bags & RavenIQ, SAT & yes/yes & NS & mixed \\
\hline Ortoleva 2014 & & $\begin{array}{l}\text { Ambiguity, } \\
\text { Cpd risk }\end{array}$ & MPLs & $\begin{array}{l}\text { Overconfidence, } \\
\text { Overplacement }\end{array}$ & & & \\
\hline
\end{tabular}

Notes: - = no information; NS = non-significant relationship;

Sample size: $\mathrm{R}=$ representative; $\mathrm{ST}=$ students; $\mathrm{SOEP}=$ German Socio-Economic Panel Study;

Measured attitudes: Risk, Ambiguity, Cpd risk (compound risk) = tasks with real incentives; Risk Hyp = hypothetical task;

Elicitation: BDM = Becker-DeGroot-Marschak method (Becker et al., 1964); MPL = Multiple Pricing List

(Holt and Laury, 2002); Choice = choice between a lottery and sure amount; Self-assessment = answer to a survey question;

Tests Cogn: RavenIQ = Raven Progressive Matrices; Hit $15=$ test of backward reasoning; NumETS = test of quantitative literacy from the Educational Testing Service; WAIS = Wechsler Adult Intelligence Scale; SAT $=$ SAT math scores; Mazes $=$ mazes similar to http://games.yahoo.com/games/maze.html; CRT = cognitive reflective test adapted from Frederick (2005);

Tests NCogn: (vers)Big5 = (version of) Big Five measures (openness to experience, neuroticism, extraversion, agreeableness, conscientiousness); SelfCtrl $=$ Self-control; FlexTh $=$ Flexible thinking; MPQ = Multidimensional Personality Questionnaire; LoC = Locus of Control;

Results: majority is RA/AA = sample is risk/ambiguity averse on average (yes/no);

Results: related to $\operatorname{Cogn} / \mathrm{NCogn}=$ attitudes to risk/ambiguity are related to cognitive/non-cognitive skills; (yes $/ \mathrm{NS} /$ mixed $=$ some measures of skills are related but some are NS related). 
Table 3: Number of sessions by treatments and by lottery prize.

\begin{tabular}{|c|l|c|c|c|}
\cline { 3 - 5 } \multicolumn{1}{c|}{} & \multicolumn{4}{c}{ Max lottery prize } \\
\cline { 2 - 5 } & 100 CZK & 200 CZK & Total \\
\cline { 2 - 5 } Lotteries presented once & 3 & 2 & 5 \\
\cline { 2 - 5 } & An order & 3 & 3 & 6 \\
\cline { 2 - 5 } & Total & 6 & 5 & 11 \\
\hline
\end{tabular}

Note: The odd number of treatments reflects the fact that not all classes were able to participate in the experiment due to various reasons.

Table 4: Description of variables

\begin{tabular}{|c|c|}
\hline prize & Prize in the lottery: $100 \mathrm{CZK}$ or $200 \mathrm{CZK}(\approx \$ 6.58$ and $\$ 13.15$ in $2013 \mathrm{PPP})$ \\
\hline $\mathrm{L}_{R}$ & Value of a risky lottery: Middle value between two values closest to the switching point in the MPL \\
\hline $\mathrm{L}_{C}$ & Value of a compound lottery: Middle value between two values closest to the switching point in the MPL \\
\hline $\mathrm{L}_{A}$ & Value of a ambiguous lottery: Middle value between two values closest to the switching point in the MPL \\
\hline $\mathrm{AmbN}$ & Ambiguity neutrality: Binary variable, "1" when $\mathrm{L}_{R}=\mathrm{L}_{A}$, "0" otherwise \\
\hline RoCL & Reduction of compound lotteries: Binary variable, "1" when $\mathrm{L}_{R}=\mathrm{L}_{C}$, "0" otherwise \\
\hline RA & Attitude towards risk: $1-\mathrm{L}_{R} /$ prize \\
\hline $\mathrm{CA}$ & Attitude towards compound risk: $1-\mathrm{L}_{C} /$ prize \\
\hline $\mathrm{AA}$ & Attitude towards ambiguity: $1-\mathrm{L}_{A} /$ prize \\
\hline $\mathrm{CA}_{\text {rel }}$ & Attitude towards compound risk relative to risk: $\left(\mathrm{L}_{R}-\mathrm{L}_{C}\right) /$ prize \\
\hline $\mathrm{AA}_{r e l}$ & Attitude towards ambiguity relative to risk: $\left(\mathrm{L}_{R}-\mathrm{L}_{A}\right) /$ prize \\
\hline female & Binary variable, "1" when female, "0" when male \\
\hline capital & Binary variable, "1" when the school from the subject study is located in Prague, "0" otherwise \\
\hline AT score & $\begin{array}{l}\text { Arithmetic Test score: Number of correctly solved groups of problems (each group consisted of four separate } \\
\text { problems, one per each arithmetic sign). Subjects were explicitly told that only correctly solved groups will } \\
\text { be counted. }\end{array}$ \\
\hline AT score PRB & Arithmetic Test score by problem: Total number of correctly solved problems. \\
\hline WMT score & Working Memory Test score: Score in the working memory (operation span memory) test \\
\hline judgconf & Judgmental confidence \\
\hline mathanx & Math anxiety \\
\hline needcog & Need for cognition \\
\hline persev & Perseverance \\
\hline premed & Premediation \\
\hline sens & Sensation seeking \\
\hline
\end{tabular}


Table 5: Descriptive statistics for lotteries and tests

\begin{tabular}{|c|c|c|c|c|c|c|c|c|}
\hline \multirow[b]{2}{*}{ Variable } & \multicolumn{4}{|c|}{ Lottery $100 \mathrm{CZK}$} & \multicolumn{4}{|c|}{ Lottery $200 \mathrm{CZK}$} \\
\hline & \# of obs & Mean & Med & $\mathrm{SD}$ & \# of obs & Mean & Med & $\mathrm{SD}$ \\
\hline $\mathrm{L}_{R}$ & 93 & 49.946 & 55 & 18.155 & 69 & 86.812 & 90 & 29.230 \\
\hline $\mathrm{L}_{C}$ & 93 & 46.935 & 45 & 18.548 & 69 & 81.884 & 90 & 29.370 \\
\hline $\mathrm{L}_{A}$ & 93 & 45.645 & 45 & 19.989 & 69 & 81.884 & 90 & 32.051 \\
\hline $\mathrm{AmbN}$ & 93 & 0.452 & 0 & 0.500 & 69 & 0.377 & 0 & 0.488 \\
\hline RCL & 93 & 0.484 & 0 & 0.502 & 69 & 0.362 & 0 & 0.484 \\
\hline RA & 93 & 0.501 & 0.45 & 0.182 & 69 & 0.566 & 0.55 & 0.146 \\
\hline $\mathrm{CA}$ & 93 & 0.531 & 0.55 & 0.185 & 69 & 0.591 & 0.55 & 0.147 \\
\hline $\mathrm{AA}$ & 93 & 0.544 & 0.55 & 0.200 & 69 & 0.591 & 0.55 & 0.160 \\
\hline $\mathrm{CA}_{r e l}$ & 93 & 0.030 & 0 & 0.106 & 69 & 0.025 & 0 & 0.167 \\
\hline $\mathrm{AA}_{r e l}$ & 93 & 0.043 & 0 & 0.162 & 69 & 0.025 & 0 & 0.144 \\
\hline female & 93 & 0.376 & 0 & 0.487 & 69 & 0.449 & 0 & 0.501 \\
\hline capital & 93 & 0.581 & 1 & 0.496 & 69 & 0.507 & 1 & 0.504 \\
\hline AT score & 93 & 4.946 & 5 & 2.252 & 69 & 5.333 & 6 & 2.616 \\
\hline AT score PRB & 93 & 24.925 & 24 & 7.075 & 69 & 26.507 & 27 & 8.668 \\
\hline WMT score & 93 & 51.258 & 53 & 11.595 & 69 & 48.884 & 47 & 12.504 \\
\hline judgconf & 93 & 2.478 & 2.4 & 0.433 & 69 & 2.517 & 2.5 & 0.481 \\
\hline mathanx & 93 & 2.517 & 2.5 & 0.720 & 69 & 2.722 & 2.8 & 0.836 \\
\hline needcog & 93 & 2.411 & 2.417 & 0.415 & 69 & 2.447 & 2.417 & 0.433 \\
\hline persev & 93 & 2.822 & 2.85 & 0.453 & 69 & 2.969 & 3 & 0.395 \\
\hline premed & 93 & 2.863 & 2.909 & 0.523 & 69 & 2.951 & 2.955 & 0.380 \\
\hline sens & 93 & 3.007 & 3.083 & 0.584 & 69 & 3.077 & 3.083 & 0.486 \\
\hline
\end{tabular}

Table 6: Correlations among lotteries valuations

\begin{tabular}{|c|c|c|c|c|c|c|c|}
\hline & \multicolumn{3}{|c|}{ Lottery $100 \mathrm{CZK}$} & & \multicolumn{3}{|c|}{ Lottery $200 \mathrm{CZK}$} \\
\hline & $\mathrm{L}_{R}$ & $\mathrm{~L}_{C}$ & $\mathrm{~L}_{A}$ & & $\mathrm{~L}_{R}$ & $\mathrm{~L}_{C}$ & $\mathrm{~L}_{A}$ \\
\hline $\mathrm{L}_{C}$ & $\begin{array}{l}\mathbf{0 . 8 3 3 1} \\
(0.0000)\end{array}$ & 1.0000 & & $\mathrm{~L}_{C}$ & $\begin{array}{c}\mathbf{0 . 3 5 3 1} \\
(0.0029)\end{array}$ & 1.0000 & \\
\hline $\mathrm{L}_{A}$ & $\begin{array}{l}\mathbf{0 . 6 4 1 0} \\
(0.0000)\end{array}$ & $\begin{array}{c}\mathbf{0 . 7 7 6 4} \\
(0.0000)\end{array}$ & 1.0000 & $\mathrm{~L}_{A}$ & $\begin{array}{c}\mathbf{0 . 5 6 2 2} \\
(0.0000)\end{array}$ & $\begin{array}{c}\mathbf{0 . 5 6 0 1} \\
(0.0000)\end{array}$ & 1.0000 \\
\hline
\end{tabular}




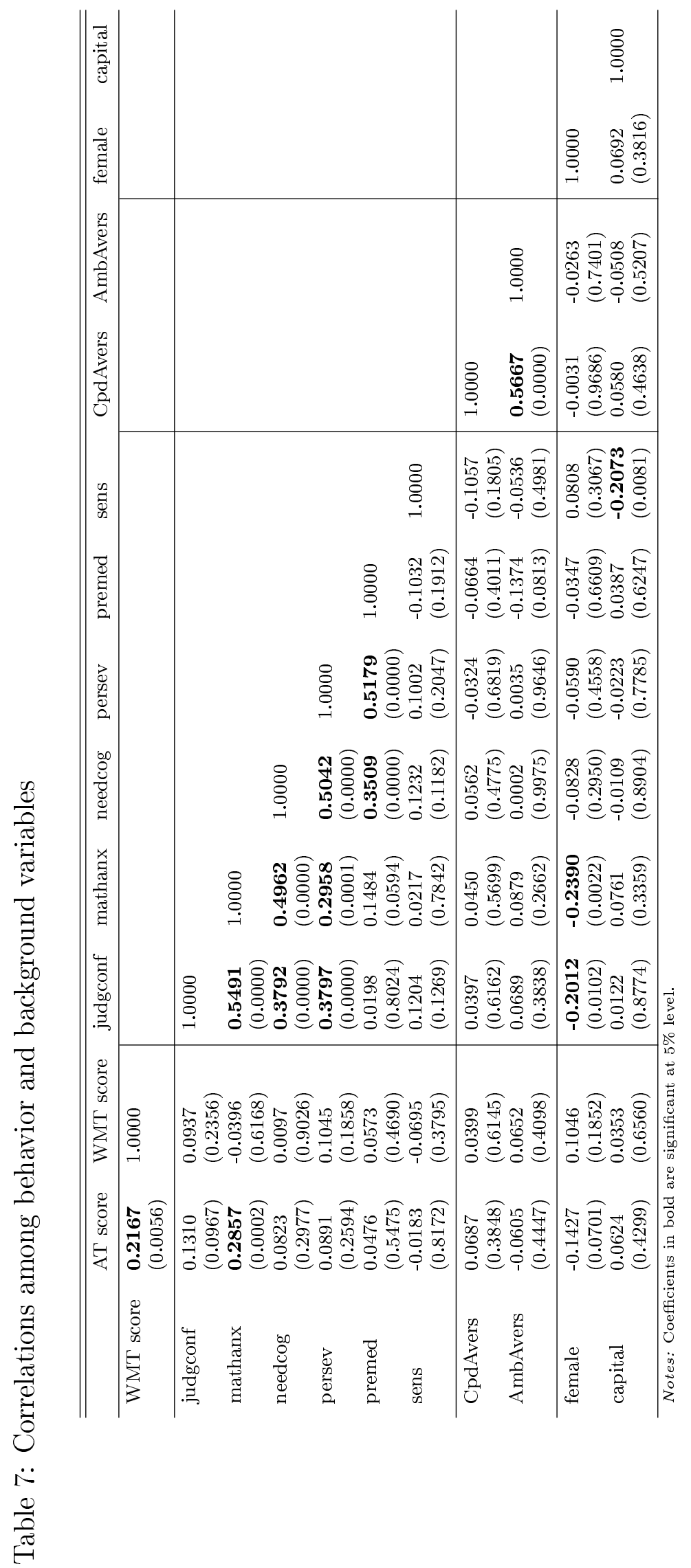



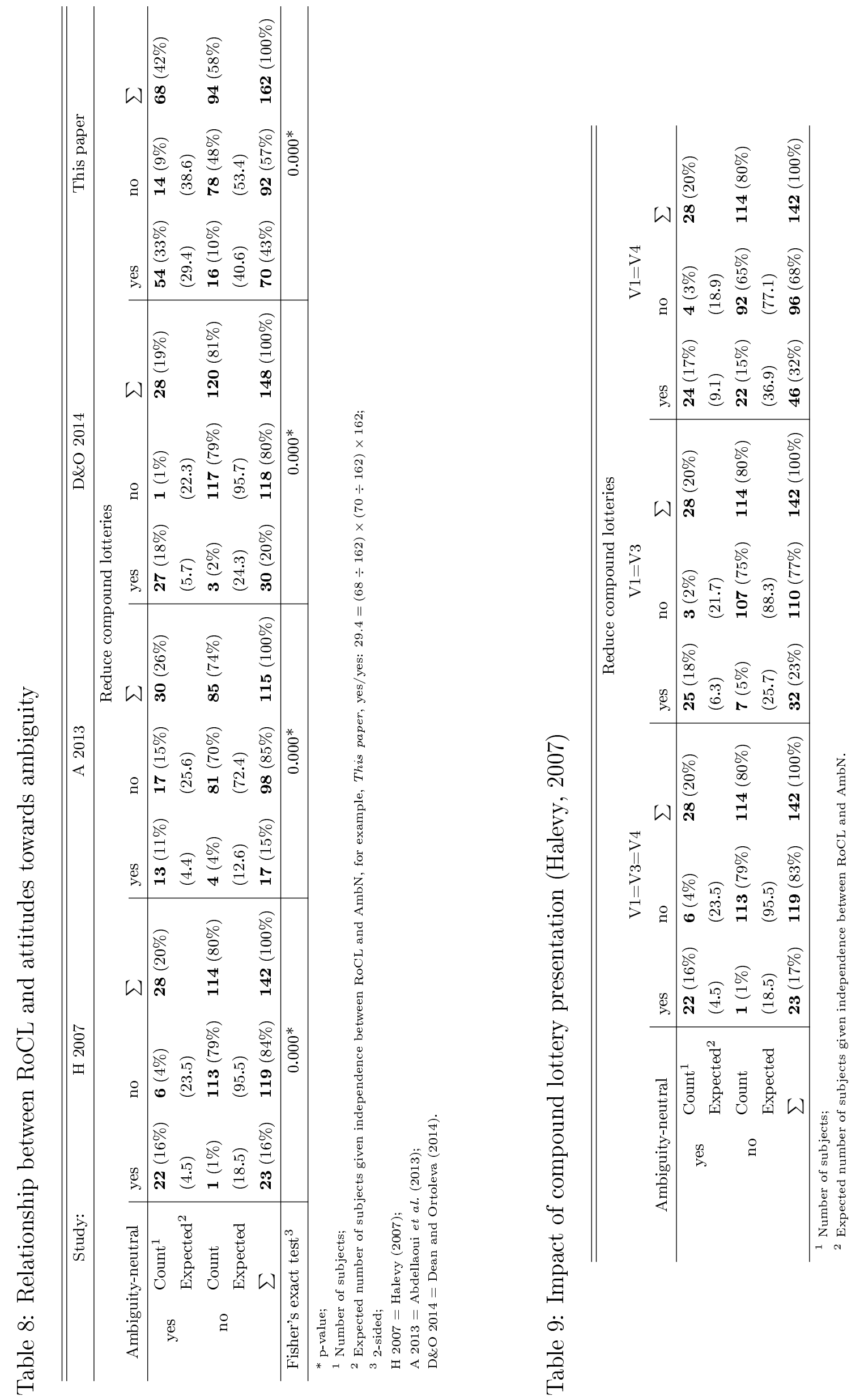


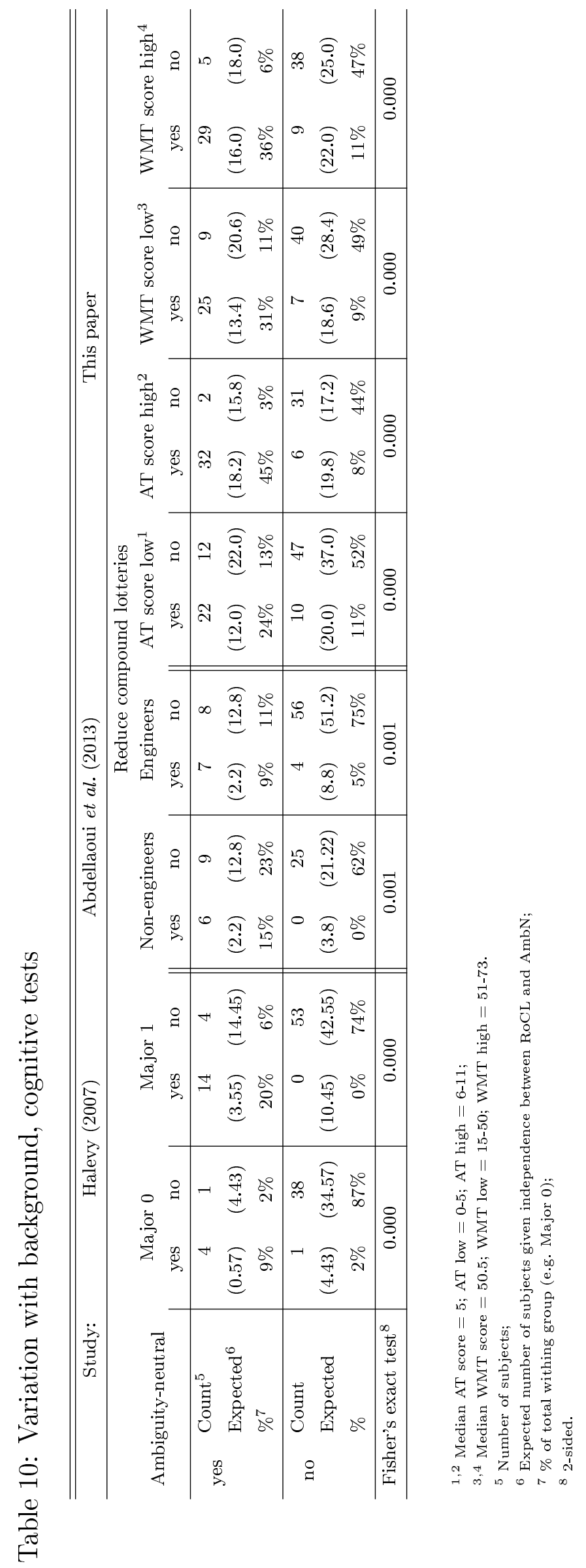


Table 11: Ambiguity-neutrality, RoCL and cognitive skills

\begin{tabular}{|c|c|c|c|c|}
\hline \multirow[t]{2}{*}{ Dependent var } & \multicolumn{2}{|c|}{$\mathrm{AmbN}$} & \multicolumn{2}{|c|}{ RoCL } \\
\hline & (1) & $(2)$ & (3) & (4) \\
\hline \multirow[t]{2}{*}{ AT score } & $0.029^{*}$ & 0.021 & $0.037^{* *}$ & $0.028^{*}$ \\
\hline & $(0.016)$ & $(0.016)$ & $(0.016)$ & $(0.015)$ \\
\hline \multirow[t]{2}{*}{ WMT score } & -0.000 & 0.000 & 0.002 & 0.003 \\
\hline & $(0.003)$ & $(0.003)$ & $(0.003)$ & $(0.003)$ \\
\hline \multirow[t]{2}{*}{ female } & & $-0.196^{* *}$ & & $-0.211^{* *}$ \\
\hline & & $(0.073)$ & & $(0.073)$ \\
\hline \multirow[t]{2}{*}{ capital } & & $0.172^{* *}$ & & 0.120 \\
\hline & & $(0.072)$ & & $(0.073)$ \\
\hline Preuso- $\mathrm{R}^{2}$ & 0.014 & 0.062 & 0.028 & 0.070 \\
\hline LR (p-value) & $3.2(0.206)$ & $13.8(0.008)$ & $6.2(0.045)$ & $15.6(0.004)$ \\
\hline Observations & 162 & 162 & 162 & 162 \\
\hline
\end{tabular}

Table 12: Relationship between RoCL and attitudes towards ambiguity, by treatment

\begin{tabular}{|c|c|c|c|c|c|c|c|}
\hline & \multicolumn{2}{|l|}{ Treatment: } & \multicolumn{2}{|l|}{ At once } & \multicolumn{3}{|c|}{ In order } \\
\hline & & & & Reduce comp & und lotteri & & \\
\hline \multicolumn{2}{|c|}{ Ambiguity-neutral } & yes & no & $\sum$ & yes & no & $\sum$ \\
\hline \multirow{2}{*}{ yes } & Count $^{1}$ & $\mathbf{2 5}(36 \%)$ & $4(6 \%)$ & $29(42 \%)$ & $29(31 \%)$ & $10(11 \%)$ & $39(42 \%)$ \\
\hline & Expected $^{2}$ & $(14.7)$ & $(14.3)$ & & $(14.7)$ & $(24.3)$ & \\
\hline \multirow{3}{*}{ no } & Count & $10(15 \%)$ & $30(43 \%)$ & $40(58 \%)$ & $6(6 \%)$ & $48(52 \%)$ & $\mathbf{5 4}(58 \%)$ \\
\hline & Expected & $(20.3)$ & $(19.7)$ & & $(20.3)$ & $(33.7)$ & \\
\hline & $\sum$ & $35(51 \%)$ & $\mathbf{3 4}(49 \%)$ & $69(100 \%)$ & $\mathbf{3 5}(37 \%)$ & $\mathbf{5 8}(63 \%)$ & $93(100 \%)$ \\
\hline \multicolumn{2}{|c|}{ Fisher's exact test (2-sided) } & \multicolumn{3}{|c|}{$0.000^{*}$} & \multicolumn{3}{|c|}{$0.000^{*}$} \\
\hline
\end{tabular}

Table 13: Ambiguity-neutrality, RoCL and cognitive skills, by treatment

\begin{tabular}{|c|c|c|c|c|c|c|c|c|}
\hline \multirow{3}{*}{$\begin{array}{l}\text { Treatment } \\
\text { Dependent var }\end{array}$} & \multicolumn{4}{|c|}{ At once } & \multicolumn{4}{|c|}{ In order } \\
\hline & \multicolumn{2}{|c|}{$\mathrm{AmbN}$} & \multicolumn{2}{|c|}{ RoCL } & \multicolumn{2}{|c|}{$\mathrm{AmbN}$} & \multicolumn{2}{|c|}{ RoCL } \\
\hline & (1) & $(2)$ & (3) & (4) & $(5)$ & (6) & $(7)$ & (8) \\
\hline \multirow[t]{2}{*}{ AT score } & $0.049 * *$ & $0.051 * *$ & $0.074 * *$ & $0.066^{* *}$ & 0.023 & 0.020 & 0.024 & 0.021 \\
\hline & $(0.024)$ & $(0.024)$ & $(0.021)$ & $(0.023)$ & $(0.021)$ & $(0.021)$ & $(0.021)$ & $(0.021)$ \\
\hline \multirow[t]{2}{*}{ WMT score } & $0.010^{* *}$ & $0.009 * *$ & $0.012^{* *}$ & $0.011^{* *}$ & $-0.008^{*}$ & -0.007 & -0.004 & -0.003 \\
\hline & $(0.004)$ & $(0.004)$ & $(0.004)$ & $(0.004)$ & $(0.004)$ & $(0.004)$ & $(0.004)$ & $(0.004)$ \\
\hline \multirow[t]{2}{*}{ female } & & -0.116 & & $-0.222^{* *}$ & & $-0.183^{*}$ & & -0.119 \\
\hline & & $(0.107)$ & & $(0.099)$ & & $(0.097)$ & & $(0.100)$ \\
\hline \multirow[t]{2}{*}{ capital } & & $0.349 * *$ & & $0.236^{* *}$ & & 0.022 & & 0.024 \\
\hline & & $(0.080)$ & & $(0.093)$ & & $(0.101)$ & & $(0.100)$ \\
\hline Preuso-R ${ }^{2}$ & 0.097 & 0.237 & 0.175 & 0.278 & 0.029 & 0.055 & 0.015 & 0.026 \\
\hline LR (p-value) & $9.1(0.010)$ & $22.3(0.000)$ & $16.7(0.000)$ & $26.6(0.000)$ & $3.7(0.160)$ & $7.0(0.139)$ & $1.9(0.398)$ & $3.2(0.524)$ \\
\hline Observations & 69 & 69 & 69 & 69 & 93 & 93 & 93 & 93 \\
\hline
\end{tabular}




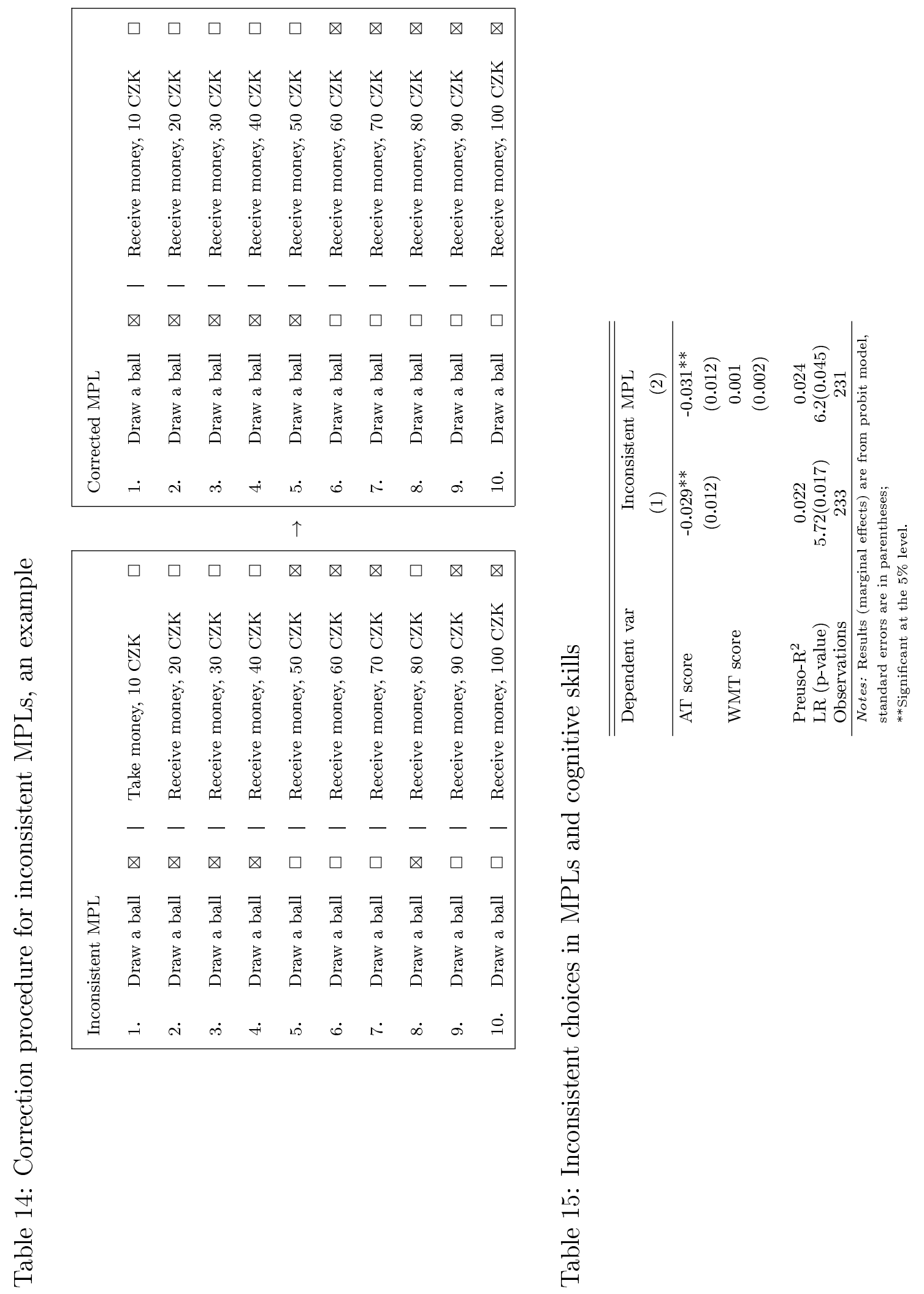


Table 16: Mean lottery valuations, by prize

\begin{tabular}{|c|c|c|c|c|c|c|}
\hline & \multicolumn{3}{|c|}{ Lottery 100 CZK } & \multicolumn{3}{|c|}{ Lottery $200 \mathrm{CZK}$} \\
\hline & Task \#1 & Task \#2 & Task \#3 & Task \#1 & Task \#2 & Task \#3 \\
\hline $\mathrm{L}_{R}$ & 47.7 & 52.8 & 47.7 & 85.6 & 78 & 97.1 \\
\hline $\mathrm{L}_{C}$ & 47.4 & 45.3 & 47.9 & 82.9 & 68 & 81.6 \\
\hline $\mathrm{L}_{A}$ & 49.7 & 46.4 & 40.5 & 74 & 86.3 & 68 \\
\hline Average & 48.3 & 48.1 & 45.4 & 80.8 & 77.4 & 82.2 \\
\hline
\end{tabular}

Table 17: Does lottery valuation depend on the absolute order of presentation?

\begin{tabular}{|c|c|c|c|c|}
\hline \multicolumn{3}{|c|}{ Lottery $100 \mathrm{CZK}$} & \multicolumn{2}{|l|}{ Lottery $200 \mathrm{CZK}$} \\
\hline $\mathrm{H}_{0}: \mathrm{L}_{R}(\mathrm{R}$ is $1 \mathrm{st})$ & $=\mathrm{L}_{R}(\mathrm{R}$ is $2 \mathrm{nd}$ or $3 \mathrm{rd})$ & $\mathrm{p}=0.3583$ & $\mathrm{H}_{0}: \mathrm{L}_{R}(\mathrm{R}$ is $1 \mathrm{st})=\mathrm{L}_{R}(\mathrm{R}$ is 2 nd or $3 \mathrm{rd})$, & $\mathrm{p}=0.4690$ \\
\hline $\mathrm{H}_{0}: \mathrm{L}_{C}(\mathrm{C}$ is $1 \mathrm{st})$ & $=\mathrm{L}_{C}(\mathrm{C}$ is $2 \mathrm{nd}$ or $3 \mathrm{rd})$ & $\mathrm{p}=0.4626$ & $\mathrm{H}_{0}: \mathrm{L}_{C}(\mathrm{C}$ is $1 \mathrm{st})=\mathrm{L}_{C}(\mathrm{C}$ is $2 \mathrm{nd}$ or $3 \mathrm{rd})$, & $\mathrm{p}=0.1266$ \\
\hline $\mathrm{H}_{0}: \mathrm{L}_{A}$ ( $\mathrm{A}$ is $1 \mathrm{st}$ & $=\mathrm{L}_{A}(\mathrm{~A}$ is $2 \mathrm{nd}$ or $3 \mathrm{rd})$ & $\mathrm{p}=0.0549$ & $\mathrm{H}_{0}: \mathrm{L}_{A}(\mathrm{~A}$ is $1 \mathrm{st})=\mathrm{L}_{A}(\mathrm{~A}$ is 2 nd or $3 \mathrm{rd})$, & $\mathrm{p}=0.6831$ \\
\hline
\end{tabular}

Table 18: Does lottery valuation depend on the relative order of presentation?

\begin{tabular}{|c|c|c|c|}
\hline \multicolumn{2}{|l|}{ Lottery $100 \mathrm{CZK}$} & \multicolumn{2}{|l|}{ Lottery $200 \mathrm{CZK}$} \\
\hline $\mathrm{H}_{0}: \mathrm{L}_{R}(\mathrm{R}$ before $\mathrm{C})=\mathrm{L}_{R}(\mathrm{R}$ after $\mathrm{C})$, & $\mathrm{p}=0.9341$ & $\mathrm{H}_{0}: \mathrm{L}_{R}(\mathrm{R}$ before $\mathrm{C})=\mathrm{L}_{R}(\mathrm{R}$ after $\mathrm{C})$ & $\mathrm{p}=0.1100$ \\
\hline $\mathrm{H}_{0}: \mathrm{L}_{R}(\mathrm{R}$ before $\mathrm{A})=\mathrm{L}_{R}(\mathrm{R}$ after $\mathrm{A})$, & $\mathrm{p}=0.7425$ & $\mathrm{H}_{0}: \mathrm{L}_{R}(\mathrm{R}$ before $\mathrm{A})=\mathrm{L}_{R}(\mathrm{R}$ after $\mathrm{A})$, & $\mathrm{p}=0.4690$ \\
\hline $\mathrm{H}_{0}: \mathrm{L}_{C}(\mathrm{C}$ before $\mathrm{R})=\mathrm{L}_{C}(\mathrm{C}$ after $\mathrm{R})$, & $\mathrm{p}=0.5882$ & $\mathrm{H}_{0}: \mathrm{L}_{C}(\mathrm{C}$ before $\mathrm{R})=\mathrm{L}_{C}(\mathrm{C}$ after $\mathrm{R})$ & $\mathrm{p}=0.1266$ \\
\hline $\mathrm{H}_{0}: \mathrm{L}_{C}(\mathrm{C}$ before $\mathrm{A})=\mathrm{L}_{C}(\mathrm{C}$ after $\mathrm{A})$, & $\mathrm{p}=0.9488$ & $\mathrm{H}_{0}: \mathrm{L}_{C}(\mathrm{C}$ before $\mathrm{A})=\mathrm{L}_{C}(\mathrm{C}$ after $\mathrm{A})$, & $\mathrm{p}=0.7733$ \\
\hline $\mathrm{H}_{0}: \mathrm{L}_{A}(\mathrm{~A}$ before $\mathrm{R})=\mathrm{L}_{A}(\mathrm{~A}$ after $\mathrm{R})$, & $\mathrm{p}=0.0549$ & $\mathrm{H}_{0}: \mathrm{L}_{A}(\mathrm{~A}$ before $\mathrm{R})=\mathrm{L}_{A}(\mathrm{~A}$ after $\mathrm{R})$ & $\mathrm{p}=0.3317$ \\
\hline $\mathrm{H}_{0}: \mathrm{L}_{A}($ A before $\mathrm{C})=\mathrm{L}_{A}($ A after $\mathrm{C})$, & $\mathrm{p}=0.0496$ & $\mathrm{H}_{0}: \mathrm{L}_{A}($ A before $\mathrm{C})=\mathrm{L}_{A}(\mathrm{~A}$ after $\mathrm{C})$ & $\mathrm{p}=0.6749$ \\
\hline
\end{tabular}

Table 19: Does lottery valuation depend on the order relative to unrelated experimental task?

\begin{tabular}{ll}
\hline \hline Lottery 200 CZK \\
\hline $\mathrm{H}_{0}: \mathrm{L}_{R}$ (before exp) $=\mathrm{L}_{R}($ after exp), & $\mathrm{p}=0.2772$ \\
$\mathrm{H}_{0}: \mathrm{L}_{C}$ (before exp) $=\mathrm{L}_{C}($ after exp), & $\mathrm{p}=0.1753$ \\
$\mathrm{H}_{0}: \mathrm{L}_{A}$ (before exp) $=\mathrm{L}_{A}($ after exp), & $\mathrm{p}=0.2487$ \\
\hline Note: & All tests are Wilcoxon-Mann-Whitney tests.
\end{tabular}

Table 20: Do relative attitudes towards compound risk/ambiguity depend on prize amount?

\begin{tabular}{|c|c|}
\hline $\begin{array}{l}\mathrm{H}_{0}: \mathrm{CA}_{r e l}(\text { prize }=100)=\mathrm{CA}_{r e l}(\text { prize }=200), \\
\mathrm{H}_{0}: \mathrm{AA}_{r e l}(\text { prize }=100)=\mathrm{AA}_{r e l}(\text { prize }=200),\end{array}$ & $\begin{array}{l}\mathrm{p}=0.6300 \\
\mathrm{p}=0.7039\end{array}$ \\
\hline
\end{tabular}


Table 21: Lottery valuations comparing to mid-list values

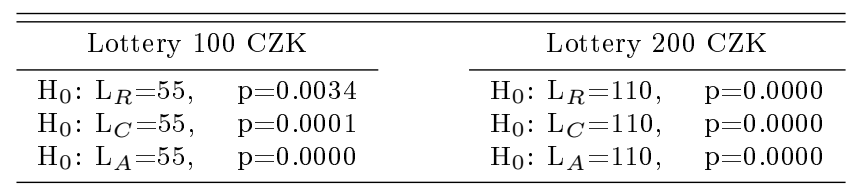

Table 22: Ambiguity-neutrality, RoCL and cognitive skills (85\% accuracy rate in WMT)

\begin{tabular}{|c|c|c|c|c|}
\hline \multirow[t]{2}{*}{ Dependent var } & \multicolumn{2}{|c|}{$\mathrm{AmbN}$} & \multicolumn{2}{|c|}{ RoCL } \\
\hline & (1) & $(2)$ & $(3)$ & $(4)$ \\
\hline \multirow[t]{2}{*}{ AT score } & $0.036^{* *}$ & 0.027 & $0.038^{* *}$ & $0.029^{*}$ \\
\hline & $(0.017)$ & $(0.017)$ & $(0.016)$ & $(0.016)$ \\
\hline \multirow[t]{2}{*}{ WMT score } & 0.001 & 0.001 & 0.004 & 0.005 \\
\hline & $(0.003)$ & $(0.003)$ & $(0.003)$ & $(0.003)$ \\
\hline \multicolumn{5}{|l|}{ Controls } \\
\hline \multirow[t]{2}{*}{ female } & & $-0.185^{* *}$ & & $-0.213^{* *}$ \\
\hline & & $(0.076)$ & & $(0.075)$ \\
\hline \multirow[t]{2}{*}{ capital } & & $0.152^{* *}$ & & 0.072 \\
\hline & & $(0.076)$ & & $(0.077)$ \\
\hline Preuso- $\mathrm{R}^{2}$ & 0.023 & 0.063 & 0.030 & 0.072 \\
\hline LR (p-value) & $4.6(0.102)$ & $12.8(0.012)$ & $7.0(0.035)$ & $14.6(0.006)$ \\
\hline Observations & 149 & 149 & 149 & 149 \\
\hline
\end{tabular}

Table 23: Ambiguity-neutrality, RoCL and cognitive skills, by treatment ( $85 \%$ accuracy rate in WMT)

\begin{tabular}{|c|c|c|c|c|c|c|c|c|}
\hline \multirow{3}{*}{$\begin{array}{l}\text { Treatment } \\
\text { Dependent var }\end{array}$} & \multicolumn{4}{|c|}{ At once } & \multicolumn{4}{|c|}{ In order } \\
\hline & \multicolumn{2}{|c|}{$\mathrm{AmbN}$} & \multicolumn{2}{|c|}{ RoCL } & \multicolumn{2}{|c|}{$\mathrm{AmbN}$} & \multicolumn{2}{|c|}{ RoCL } \\
\hline & (1) & $(2)$ & $(3)$ & $(4)$ & $(5)$ & (6) & $(7)$ & (8) \\
\hline AT score & $\begin{array}{l}0.048^{* *} \\
(0.024)\end{array}$ & $\begin{array}{l}0.045^{*} \\
(0.025)\end{array}$ & $\begin{array}{l}0.066^{* *} \\
(0.022)\end{array}$ & $\begin{array}{l}0.057^{* *} \\
(0.024)\end{array}$ & $\begin{array}{c}0.031 \\
(0.022)\end{array}$ & $\begin{array}{c}0.031 \\
(0.022)\end{array}$ & $\begin{array}{c}0.027 \\
(0.022)\end{array}$ & $\begin{array}{c}0.026 \\
(0.021)\end{array}$ \\
\hline WMT score & $\begin{array}{l}0.012^{* *} \\
(0.005)\end{array}$ & $\begin{array}{c}0.012^{* *} \\
(0.004)\end{array}$ & $\begin{array}{l}0.013^{* *} \\
(0.004)\end{array}$ & $\begin{array}{c}0.013^{* *} \\
(0.004)\end{array}$ & $\begin{array}{l}-0.007 \\
(0.004)\end{array}$ & $\begin{array}{l}-0.006 \\
(0.004)\end{array}$ & $\begin{array}{l}-0.003 \\
(0.004)\end{array}$ & $\begin{array}{l}-0.002 \\
(0.004)\end{array}$ \\
\hline Controls & & & & & & & & \\
\hline female & & $\begin{array}{l}-0.114 \\
(0.109)\end{array}$ & & $\begin{array}{c}-0.195^{*} \\
(0.104)\end{array}$ & & $\begin{array}{l}-0.166 \\
(0.101)\end{array}$ & & $\begin{array}{l}-0.141 \\
(0.103)\end{array}$ \\
\hline capital & & $\begin{array}{c}0.363^{* *} \\
(0.081)\end{array}$ & & $\begin{array}{c}0.236^{* *} \\
(0.097)\end{array}$ & & $\begin{array}{l}-0.023 \\
(0.105)\end{array}$ & & $\begin{array}{l}-0.057 \\
(0.103)\end{array}$ \\
\hline $\begin{array}{l}\text { Preuso-R }{ }^{2} \\
\text { LR (p-value) }\end{array}$ & $\begin{array}{c}0.106 \\
9.1(0.012)\end{array}$ & $\begin{array}{c}0.258 \\
22.1(0.000)\end{array}$ & $\begin{array}{c}0.186 \\
16.3(0.000)\end{array}$ & $\begin{array}{c}0.280 \\
24.5(0.000)\end{array}$ & $\begin{array}{c}0.031 \\
3.5(0.170)\end{array}$ & $\begin{array}{c}0.054 \\
6.2(0.183)\end{array}$ & $\begin{array}{c}0.015 \\
1.7(0.431)\end{array}$ & $\begin{array}{c}0.036 \\
4.0(0.407)\end{array}$ \\
\hline Observations & 63 & 63 & 63 & 63 & 86 & 86 & 86 & 86 \\
\hline
\end{tabular}




\section{Figures}

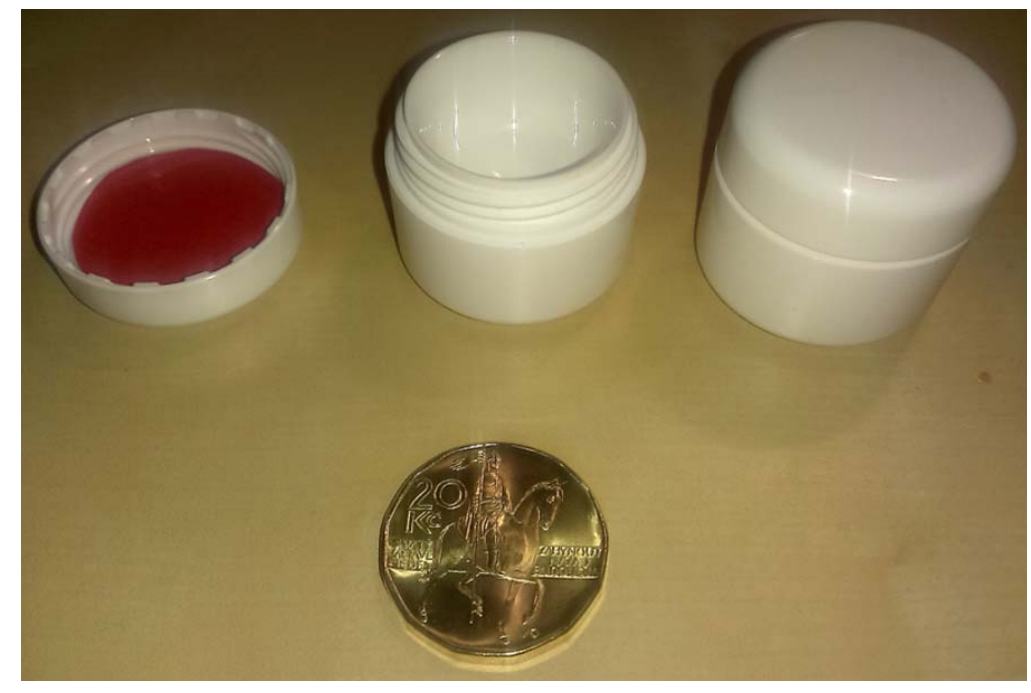

Figure 1: Containers used in the experiment
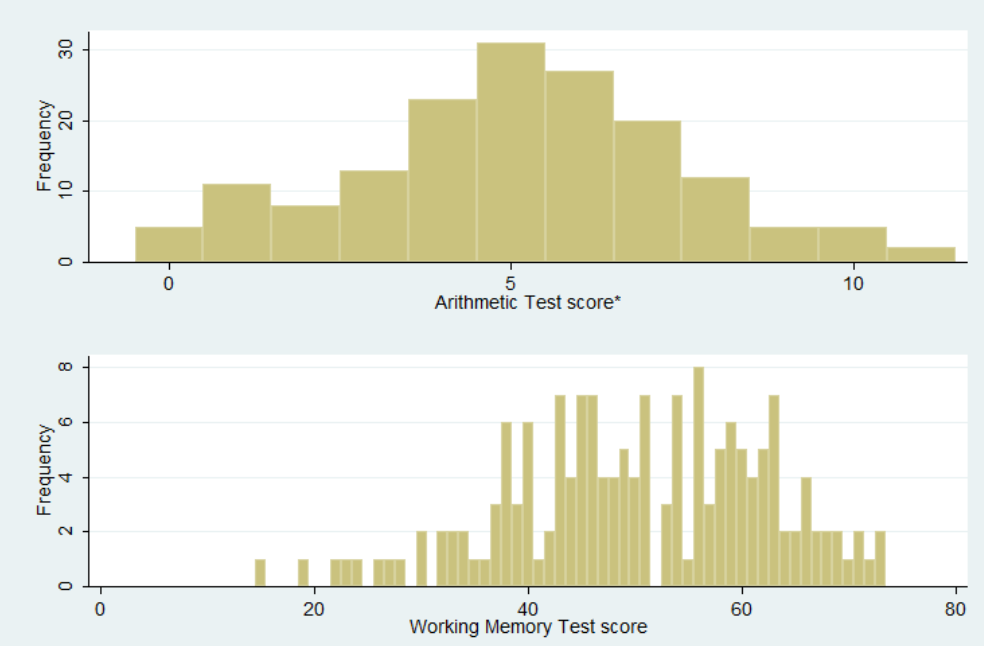

*All problems were grouped by four, one problem per each arithmetic sign Points were given only when the whole group was solved correctly.

Figure 2: Cognitive tests distributions 

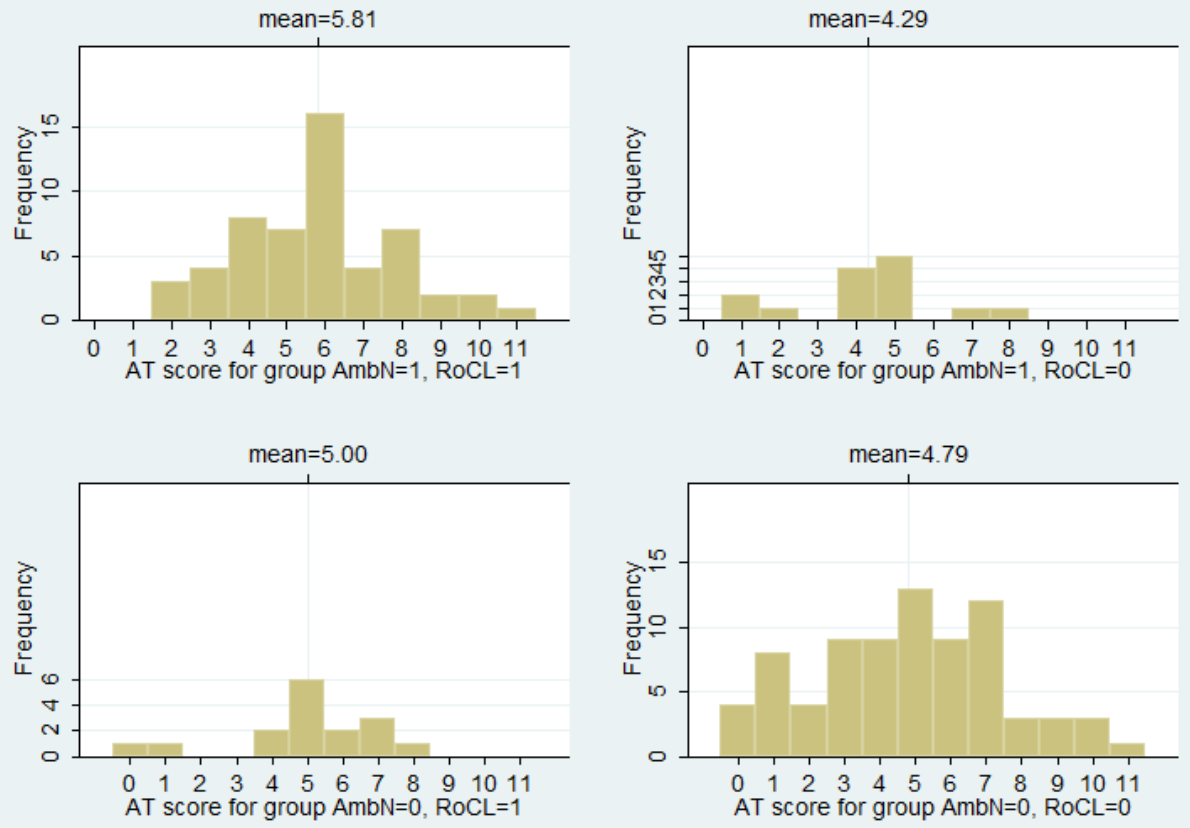

Figure 3: AT results by attitudes to ambiguity and RoCL
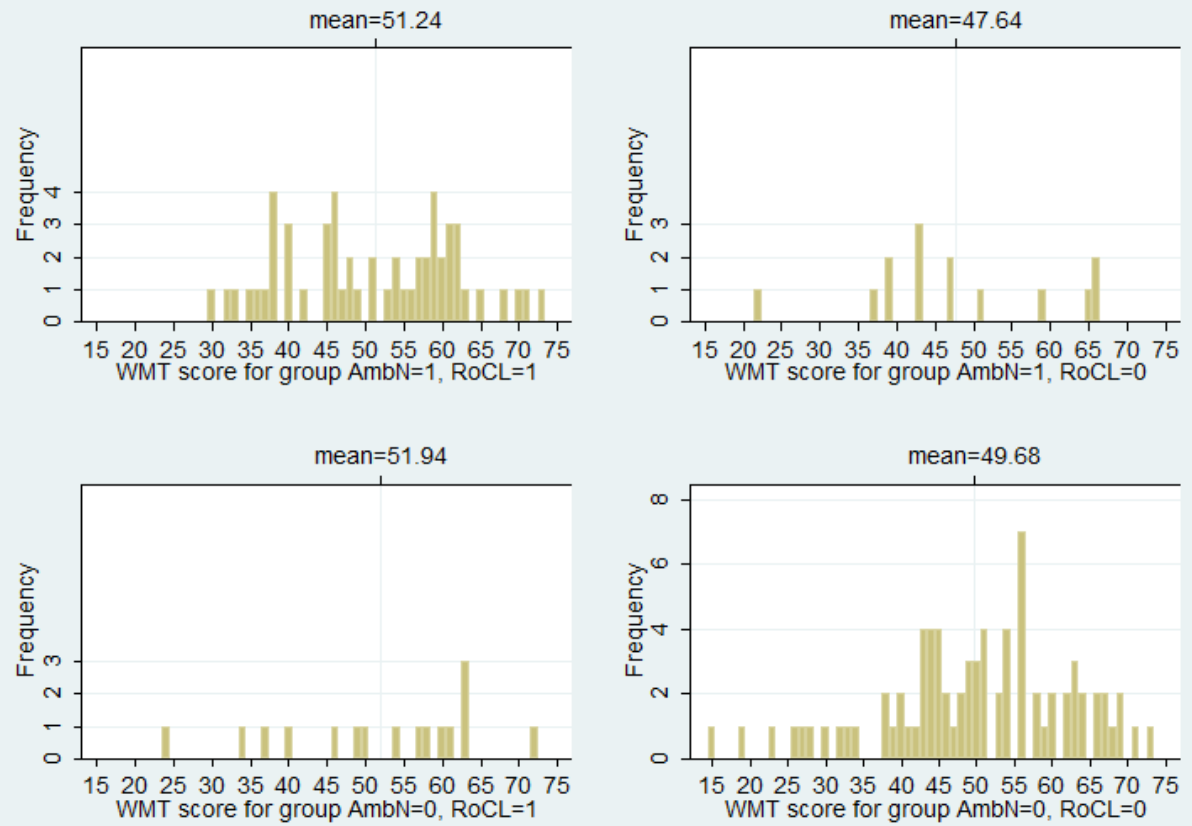

Figure 4: WMT results by attitudes to ambiguity and RoCL 

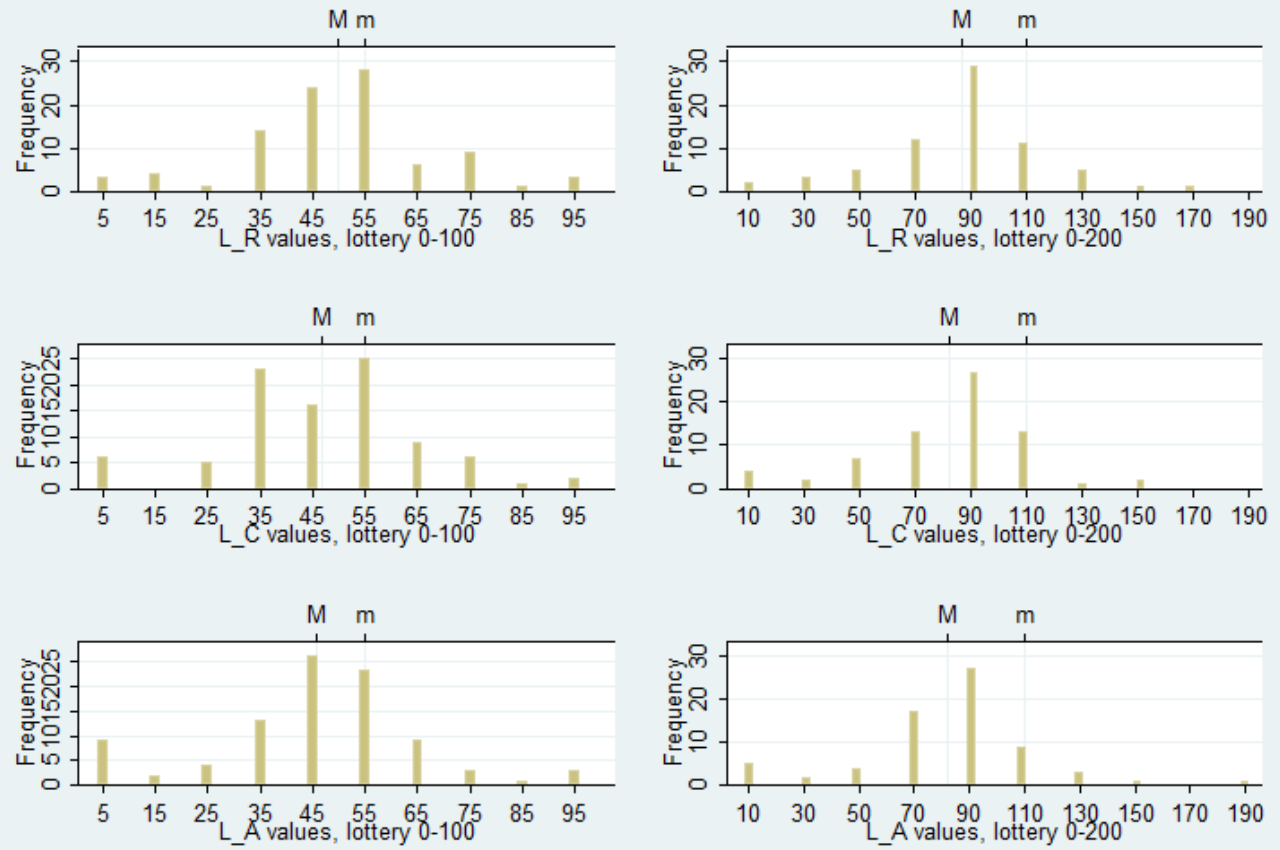

${ }^{*} \mathrm{M}=\mathrm{Mean} ; \mathrm{m}=$ middle list value

Figure 5: Valuations versus mid-list by lottery prize 


\section{Working Paper Series}

ISSN 1211-3298

Registration No. (Ministry of Culture): E 19443

Individual researchers, as well as the on-line and printed versions of the CERGE-EI Working Papers (including their dissemination) were supported from institutional support RVO 67985998 from Economics Institute of the ASCR, v. v. i.

Specific research support and/or other grants the researchers/publications benefited from are acknowledged at the beginning of the Paper.

(c) Sasha Prokosheva, 2014

All rights reserved. No part of this publication may be reproduced, stored in a retrieval system or transmitted in any form or by any means, electronic, mechanical or photocopying, recording, or otherwise without the prior permission of the publisher.

Published by

Charles University in Prague, Center for Economic Research and Graduate Education (CERGE) and

Economics Institute of the ASCR, v. v. i. (EI)

CERGE-El, Politických vězňu 7, 11121 Prague 1, tel.: +420 224005 153, Czech Republic.

Printed by CERGE-EI, Prague

Subscription: CERGE-EI homepage: http://www.cerge-ei.cz

Phone: + 420224005153

Email: office@cerge-ei.cz

Web: http://www.cerge-ei.cz

Editor: Marek Kapička

The paper is available online at http://www.cerge-ei.cz/publications/working_papers/.

ISBN 978-80-7343-330-7 (Univerzita Karlova. Centrum pro ekonomický výzkum a doktorské studium)

ISBN 978-80-7344-322-1 (Akademie věd České republiky. Národohospodářský ústav) 
CERGE-EI

P.O.BOX 882

Politických vězňů 7

11121 Praha 1

Czech Republic http://www.cerge-ei.cz 